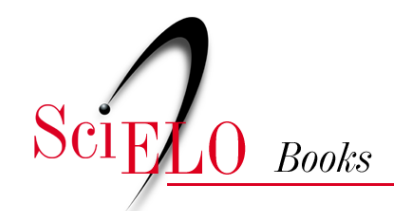

\title{
Os investimentos externos diretos da República Popular da China no território fluminense no século XXI
}

\author{
Thiago Jeremias Baptista
}

\section{SciELO Books / SciELO Livros / SciELO Libros}

BAPTISTA, T.J. Os investimentos externos diretos da República Popular da China no território fluminense no século XXI. In: MARAFON, G.J., and RIBEIRO, M.A. orgs. Revisitando o território fluminense, VI [online]. Rio de Janeiro: EDUERJ, 2017, pp. 123-150. ISBN: 978-85-7511-457-5. https://doi.org/10.7476/9788575114575.0008.

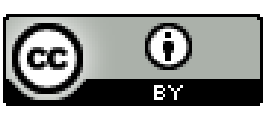

All the contents of this work, except where otherwise noted, is licensed under a Creative Commons Attribution 4.0 International license.

Todo o conteúdo deste trabalho, exceto quando houver ressalva, é publicado sob a licença Creative Commons Atribição $\underline{4.0}$.

Todo el contenido de esta obra, excepto donde se indique lo contrario, está bajo licencia de la licencia $\underline{\text { Creative Commons }}$ $\underline{\text { Reconocimento 4.0. }}$. 


\section{Os investimentos externos diretos da República Popular da China no território fluminense no século XXI}

Thiago Jeremias Baptista ${ }^{1}$

\section{Introdução}

E ste artigo é produto dos esforços empreendidos na elaboração da dissertação de mestrado, no programa de pós-graduação em Geografia da Universidade do Estado do Rio de Janeiro (PPGEO/ UERJ), no período de 2014-2016, sob a orientação do Prof. Dr. Glaucio José Marafon. Evidencia-se, aqui, a expansão dos investimentos externos diretos (IED) da República Popular da China nos países em desenvolvimento, citando a inserção do Brasil nesse processo. Identifica-se o influxo desses investimentos no estado do Rio de Janeiro no período 2010-2013.

A fim de compreendermos se o influxo de capital sínico no território fluminense conforma uma nova territorialidade no processo de reestruturação territorial, resgatamos a trajetória econômica do estado do Rio de Janeiro ao longo do século XX, evidenciando a perda de centralidade político-econômica entre 1930 e 1980, assim como o processo de reestruturação do território fluminense decorrente da reorganização do influxo de investimentos atrelada à sua interiorização econômica após a década de 1990 . Tecem-se, ainda, algumas considerações sobre a projeção daquele país asiático à condição de investidor internacional, visando relacionar o ingresso e a distribuição espacial dos investimentos chineses com o processo de reestruturação territorial fluminense.

${ }^{1}$ Bacharel e licenciado em Geografia pela UERJ; especialista em História das Relações Internacionais pelo CEHRI/UERJ; pós-graduado em Dinâmicas Urbano-Ambientais e Gestão do Território pela FFP/UERJ; e mestre em Geografia pelo PPGEO/UERJ. 


\section{A trajetória econômica fluminense no século XX e 0 processo de reestruturação territorial do estado do Rio de Janeiro}

Durante o século XX, o território fluminense se caracterizou pela perda da centralidade político-econômica. $\mathrm{O}$ exercício da centralidade política deveu-se ao fato de, durante praticamente duzentos anos (1763-1960), a cidade de São Sebastiāo do Rio de Janeiro ter exercido a capitalidade do Brasil colonial, imperial e republicano. No entanto, a transferência da capital federal para a cidade de Brasília (1960) levou à perda dessa centralidade. Ao período marcado pela perda de centralidade política, soma-se o processo de perda de centralidade econômica, em decorrência do intenso desenvolvimento industrial de São Paulo.

A centralidade econômica exercida pelo espaço fluminense está atrelada à proeminência econômica alcançada nos períodos colonial e imperial do Brasil. Como resultado de sua inserção primário-exportadora, que acompanhou o sistema social movido pelo modo de acumulação agromercatil escravista (Moreira, 2013), o espaço fluminense vivenciou, desde o século XVI, certa preocupação com as questões comercial, portuária e militar, que se somaram às funções administrativa e industrial.

Com efeito, no final do século XIX, o espaço fluminense caracterizava-se tanto por sua expressiva centralidade política quanto por sua capacidade de exercer posição hegemônica no cenário econômico nacional (Marafon et al., 2005). No entanto, ainda que, no início do século XX, o território fluminense exercesse forte influência nos campos político e econômico nacional, tanto em decorrência das funções burocráticas exercidas pela cidade do Rio como capital quanto por ter, na base de seu processo de acumulação, as atividades cafeeiras e apresentar significativo desenvolvimento portuário, comercial, administrativo, financeiro e industrial, o Rio de Janeiro assistiu, ao longo daquele século, a uma trajetória de degradação, sobretudo em função da ascensão de São Paulo, que se tornou o centro dinâmico da economia nacional.

Melo (2001), Melo e Araújo (2014) e Silva (2012) representam referenciais teóricos acerca desse processo, sobretudo por fazerem referência ao período de 1930 a 1980 sob a ótica do esvaziamento econômico e das perdas relativas, denotando uma conjuntura econômica involutiva que, além de abarcar a perda de centralidade, evidencia a menor participação do estado do Rio de Janeiro no PIB nacional e na produção industrial do país.

Os dados apresentados por Melo (2001) e Melo e Araújo (2014) apontam que, no período de 1930 a 1980, o estado do Rio de Janeiro vivenciou um período de esvaziamento econômico, decorrente de sua menor participação na produção industrial brasileira. Portanto, embora tenha sido o berço da industrialização no país, a indústria fluminense assistiu, desde a década de 1930, a um inexorável processo de esvaziamento, perdendo a posição de destaque para a indústria paulista. Para esses autores, o processo de esvaziamento do Rio de Janeiro vem desde o início do século XX, mantendo-se na passagem para os anos 1930 e sendo agravado pela contínua redução da participação do Rio de Janeiro e do Distrito Federal na produção industrial brasileira durante a segunda metade daquele século. Por seu turno, no fim da década de 1930, a participação do Rio de Janeiro, somada com a do Distrito Federal, correspondia a menos da metade da participação de São Paulo na produção industrial do país, mantendo-se essa traje- 
tória de redução da economia fluminense na produção industrial nacional ao longo de praticamente toda a segunda metade do século XX (Gráfico 1).

Gráfico 1. Rio de Janeiro e São Paulo: participação na produção industrial do Brasil entre 1907-2000

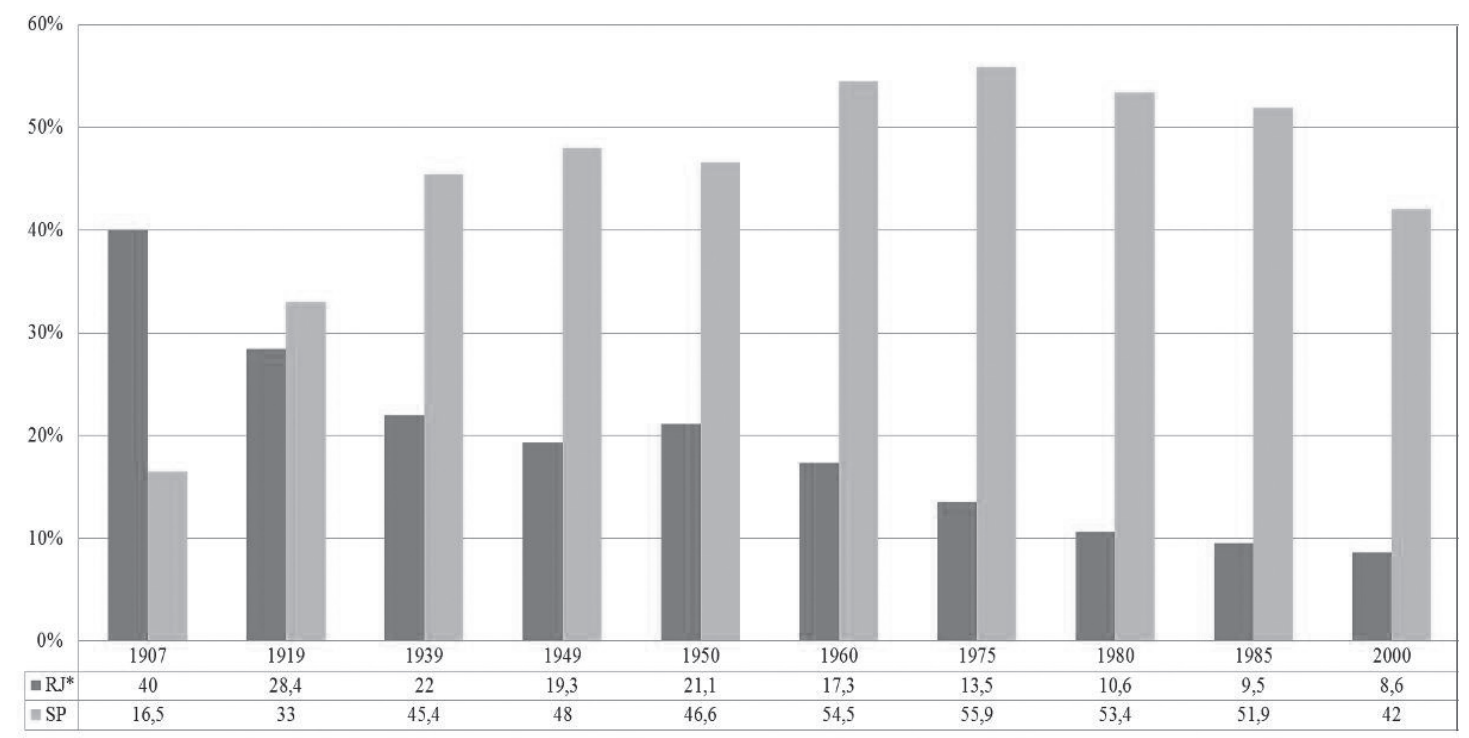

*Soma da cidade do Rio de Janeiro com o estado do Rio de Janeiro no período de 1907-1975.

Fonte: Melo (2001) e Araújo e Melo (2014). Gráfico elaborado pelo autor.

Segundo Silva, as perdas fluminenses resultam, sobretudo, da combinação entre a acelerada expansão industrial no território nacional e as perdas reais de alguns ramos da economia estadual. Assim, “o Rio de Janeiro, como espaço pioneiro de vários setores, não conseguiu acompanhar o crescimento relativo dos novos espaços, perdendo participação relativa no total nacional" (2012, p. 52). Portanto, "se fosse possível sintetizar, em uma frase, o desenvolvimento capitalista fluminense entre 1930-1980, a que melhor sintetizaria esse processo seria, muito possivelmente, crescimento e modernização com perda de importância relativa” (p. 41).

$\mathrm{Na}$ perspectiva desse autor, a dinâmica econômica fluminense foi marcada por um amplo processo de expansão e modernização de sua estrutura urbano-produtiva, caracterizando-se pela inserção mais efetiva na macrodinâmica da economia brasileira. No entanto, sua trajetória se diferenciou das demais economias estaduais do país, o que resultou em um processo de perda de participação regional na renda nacional. Para ele, essa trajetória "passou a ser comumente interpretada como um processo de esvaziamento" e de "decadência econômica regional". Assim, embora o termo esvaziamento econômico tenha sido utilizado por vários acadêmicos para denominar esse processo, segundo sua interpretação, o que ocorreu na economia fluminense foi uma trajetória de redução da participação do estado no PIB nacional. Dessa forma, fica nítido que a redução da economia fluminense apresentou um perfil relativo, ou seja, resultou do descompasso entre suas taxas e a média do país (Silva, 2012). Em consequência, houve uma contínua redução da participação do estado do Rio de Janeiro no PIB nacional durante o século XX, retraindo-se de 21\% em 1939 para 11\% em 1995 (Gráfico 2). 
Gráfico 2. Participação do estado do Rio de Janeiro no PIB nacional entre 1939-1995

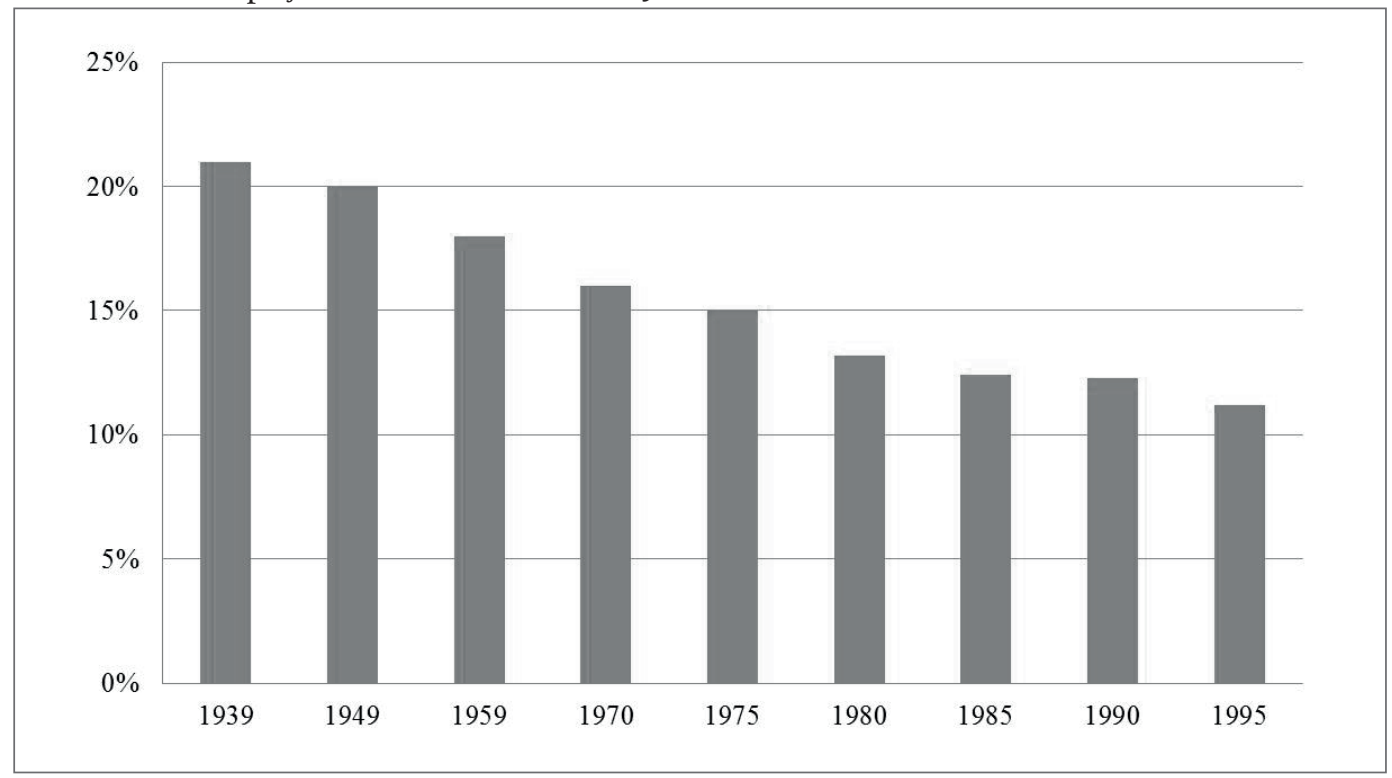

Fonte: Santos (2003); Silva (2012) e Ceperj (s.d.). Pib Estadual 1995-2012. Disponível em: http://www.ceperj.rj.gov.br/ ceep/pib/pib.html. Acesso em: 8 nov. 2015. Gráfico elaborado pelo autor.

Diante do exposto, compreende-se que a trajetória econômica fluminense ao longo do século XX foi marcada pela desestruturação de importantes setores produtivos, pela redução de sua participação na produção industrial nacional e pela consequente retração da contribuição do Rio de Janeiro no PIB nacional, implicando o ingresso do território fluminense no período denominado esvaziamento econômico e/ou de perdas relativas de participação fluminense na economia nacional, dependendo do referencial teórico escolhido (Melo, 2001; Silva, 2012; Araújo e Melo, 2014). No entanto, ainda que marcado por uma conjuntura econômica involutiva, não podemos desconsiderar que o território assistiu aos investimentos em infraestrutura e à implantação de novas atividades produtivas. Mas esses investimentos não foram capazes de reverter sua trajetória de esvaziamento econômico e/ou de perdas relativas na participação do PIB nacional.

Portanto, em consequência do desempenho negativo da economia nacional nos anos 1980, a conjuntura econômica do estado do Rio de Janeiro continuaria marcada pelo agravamento de sua trajetória de redução de participação na produção industrial brasileira e no PIB nacional. Como resultado, o estado do Rio de Janeiro teve de aguardar a década de 1990 para assistir a um conjunto de mudanças em sua base produtiva que desencadearia um processo de reestruturação. Tais mudanças são postas em tela a seguir, quando se volta a atenção à compreensão do processo de reestruturação territorial fluminense e à inserção dos investimentos chineses no estado no início do século XXI.

Compreendida como processo resultante da modificação da estrutura de um espaço material, de forma rápida ou lenta, ocorrendo em diferentes escalas em que os fatores econômicos, políticos e ideológicos, frequentemente combinados, transmitem a noção de ruptura nas tendências seculares, a reestruturação pode ser compreendida como uma mudança estrutural expressiva em direção a uma ordem e a uma configuração significativamente diferente nas vidas social, econômica e política (Soja, 1993; Santos, 2008; Souza, 2013). 
No caso do estado do Rio de Janeiro, a década de 1990 se caracterizou pela superação da trajetória de estagnação pari passu ao processo de retomada de crescimento econômico do estado, revertendo a perda de importância na economia nacional após a fase de esvaziamento econômico e/ ou de perdas relativas entre as décadas de 1930-1980. Como desdobramento desse processo, houve a retomada das atividades produtivas e a emergência de uma conjuntura liderada pelo interior fluminense, em face da dinamização de seu parque industrial, que capitaneou a reestruturação territorial do estado, conformando-o em "um território em mudança". Com efeito pouco visível no espaço metropolitano, uma nova economia regional se constituía a partir do interior do território, marcada por uma trajetória de retomada do crescimento econômico (Oliveira, 2012).

Com uma extensão de 43,7 mil km², o atual estado do Rio de Janeiro (Figura 1) estabelece divisa com outros três estados do Sudeste do Brasil, apresentando uma organização político-administrativa formada por oito regióes de governo e uma malha municipal constituída por 92 municípios.

Figura 1. Estado do Rio de Janeiro: a RMRJ e o interior fluminense

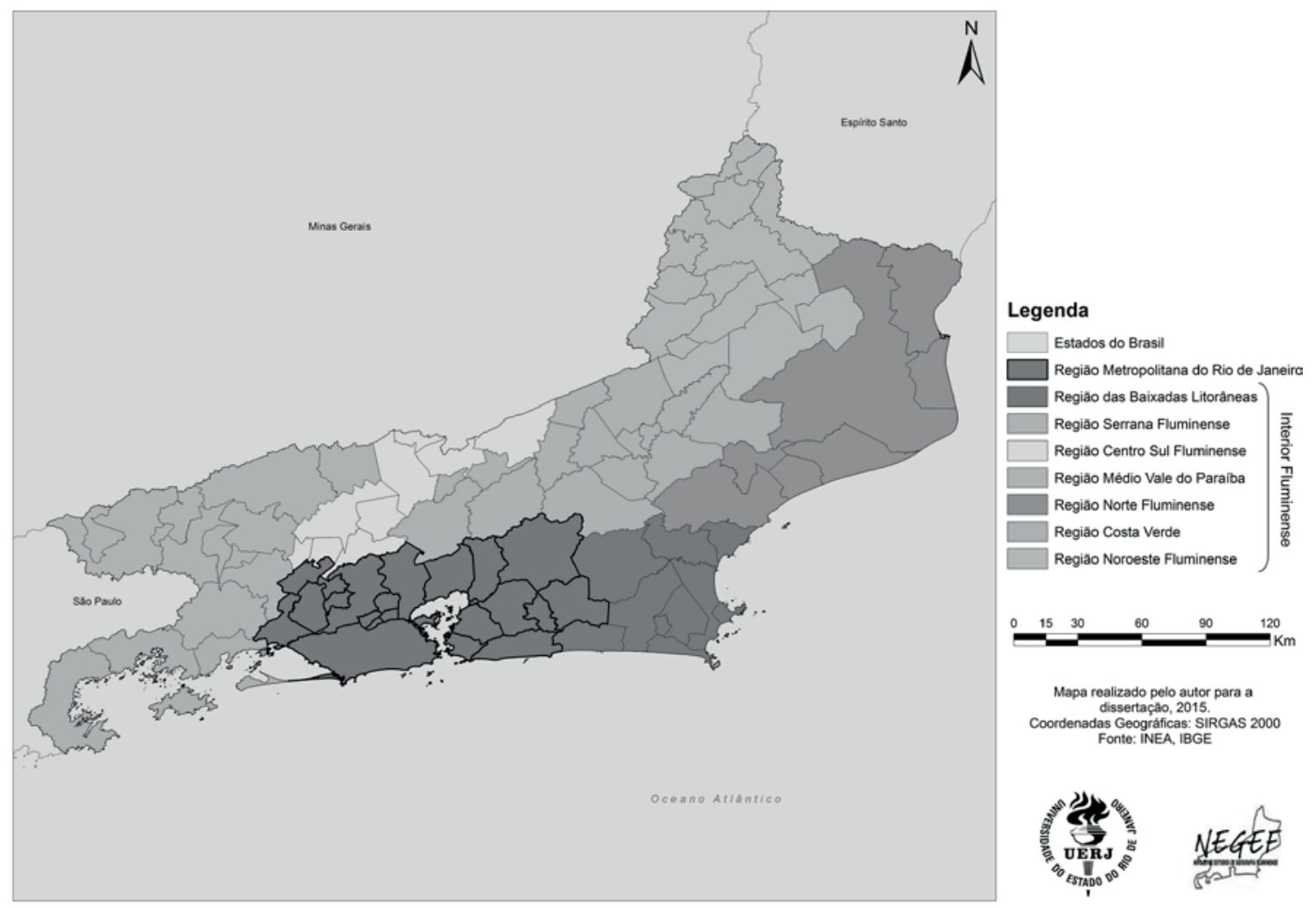

Oliveira (2008) compreende a reestruturação produtiva do território fluminense a partir da superação da crise de um modelo de industrialização centrado na cidade do Rio de Janeiro e em seu entorno, com a consequente dispersão das atividades produtivas para fora da Região Metropolitana do Rio de Janeiro. Essa dispersão decorreu da reorientação do fluxo de investimentos no território e 
da instalação de novas plantas industriais no interior fluminense, o que contribuiu para a reestruturação produtiva e a reconfiguração econômico-regional do Médio Paraíba - metalmecânico, siderometalúrgico e automobilístico - e do Norte Fluminense - onde a indústria extrativo-petrolífera e as atividades de suporte voltadas a esse setor se destacam. ${ }^{2}$

Nesse sentido, consideramos, para efeito de análise, a década de 1990, especialmente a segunda metade, o momento de retomada da economia fluminense, tanto pela continuidade da instalação de novas atividades produtivas quanto por ser um ponto de inflexão na trajetória de crescimento do PIB no estado do Rio de Janeiro. A partir desse momento, a trajetória do PIB fluminense manteve-se crescente e sua participação relativa na economia nacional, embora oscilante, apresentou tendência de crescimento entre 1995-2013, quando o PIB fluminense saltou de $\mathrm{R} \$ 78,9$ milhões em 1995 para $\mathrm{R}$ \$ 626,3 milhões em 2013, ampliando sensivelmente o percentual de participação na economia nacional, de 11\% em 1995 para aproximadamente 12\% em 2012, mantendo-se ainda em 2013 com uma participação ligeiramente superior à contribuição apresentada em meados dos anos 1990 (Gráfico 3).

Gráfico 3. Estado do Rio de Janeiro: PIB e participação no PIB nacional entre 1995-2013

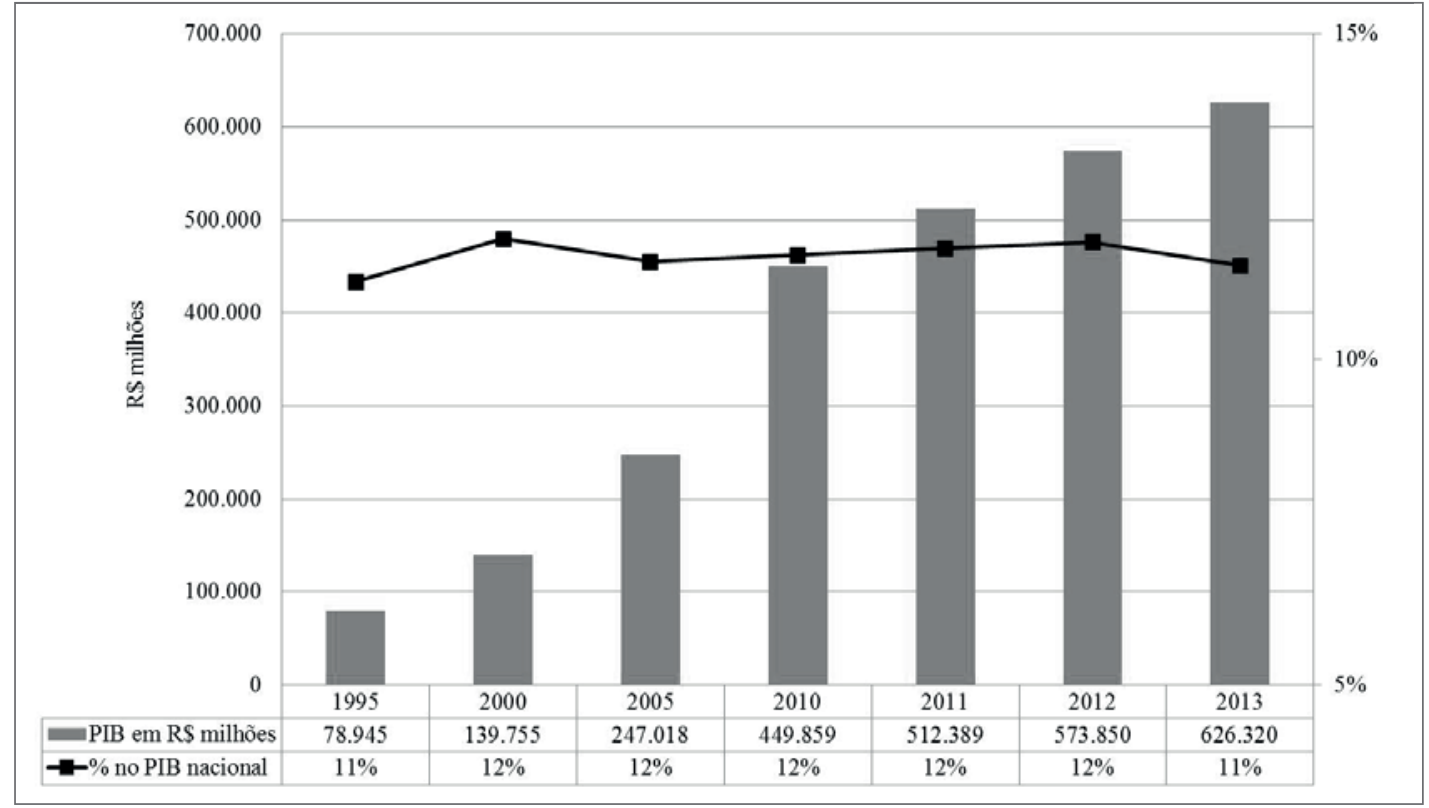

Fonte: Autor, 2015.

${ }^{2}$ Para Oliveira, o marco desse processo foi "o ano de 1994, quando teve início a extração de petróleo em escala comercial nas grandes jazidas da bacia de Campos, no norte do estado, e o anúncio da instalação da indústria automobilística com a montadora de caminhões da Volkswagen, na região do Médio Paraíba” (2012, p. 136). 


\section{Os investimentos externos diretos da República Popular da China no território fluminense}

Nas últimas décadas, a avaliação da trajetória de crescimento do PIB no estado do Rio de Janeiro viabiliza a compreensão da retomada da capacidade produtiva da economia fluminense, não deixando dúvida acerca de uma mudança na conjuntura econômica vivenciada pelo território. Nesse sentido, concordamos com as consideraçôes de Silva (2012), ao assinalar que esse processo decorre da alteração do padrão de esvaziamento para uma retomada da atividade econômica estadual, comandada pela atividade industrial, em especial a indústria extrativa petrolífera, e também por alguns setores da indústria de transformação, que, entre outros aspectos, promoveram a desconcentração das atividades produtivas no território e da produção industrial fluminense, o que contribuiu para a reestruturação da economia estadual.

Para Silva (2012), os padrões de desenvolvimento industrial do interior fluminense compreendem a especialização da produção petrolífera no Norte fluminense e a especialização da produção manufatureira do Sul fluminense. Com efeito, as regiōes de governo que compõem o recorte espacial compreendido pelo interior fluminense ganham expressão com a instalação de novas atividades produtivas, o que influiu na reversão do quadro de estagnação que perdurou até os anos 1980, dando início a um movimento de inversão da concentração de recursos, das atividades produtivas, da população e dos investimentos da Região Metropolitana em relação ao interior. Estabeleceu-se, assim, na passagem para o século XXI, um novo cenário econômico no território fluminense, mantido pela tendência de expansão econômica do interior do estado, em oposição à retração da participação da Região Metropolitana no PIB do estado do Rio de Janeiro (Gráfico 4).

Gráfico 4. Estado do Rio de Janeiro: participação da RMRJ e interior fluminense no PIB (2000-2012)

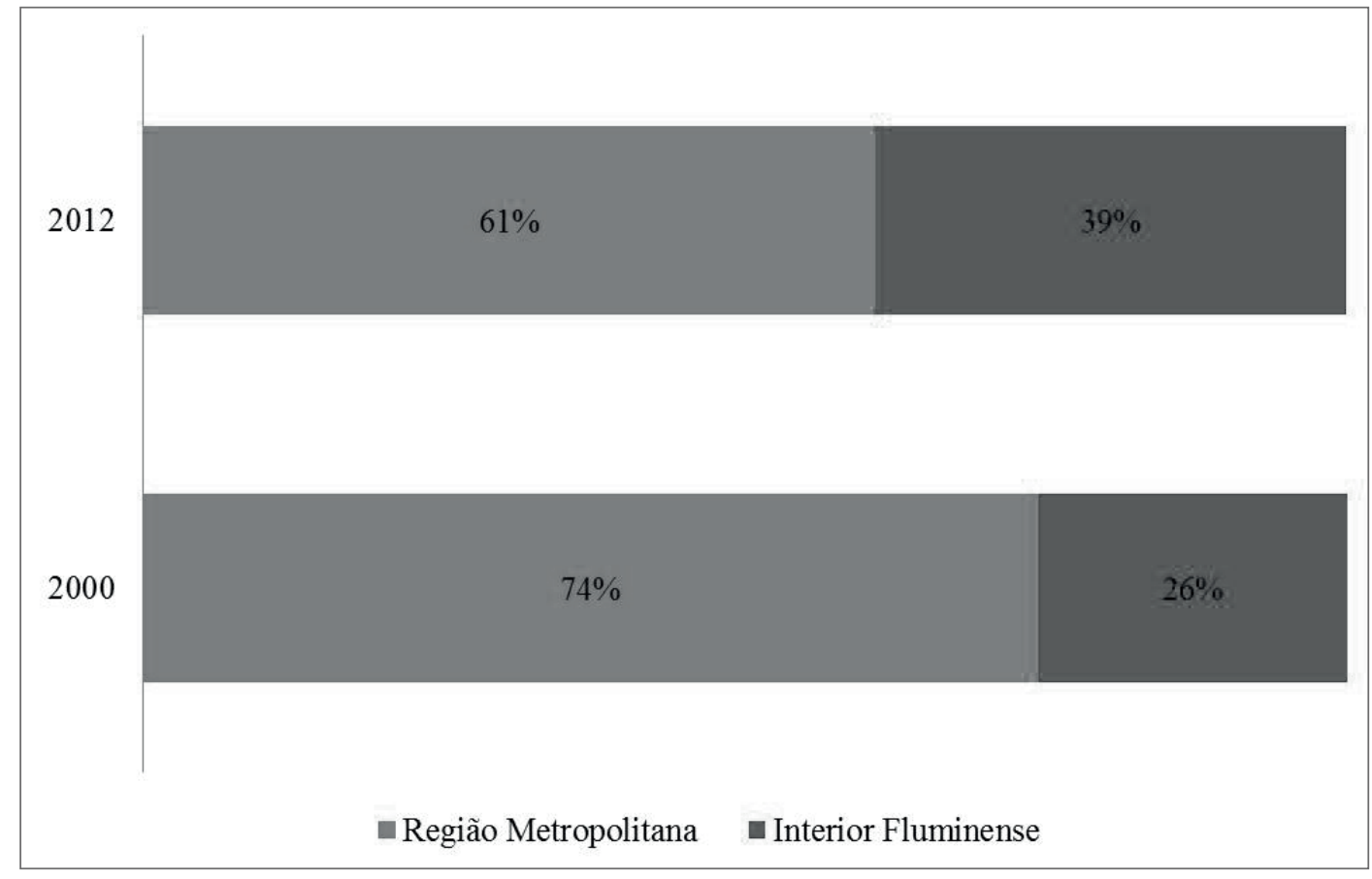

Fonte: Fundação Ceperj. Disponível em: http://www.ceperj.rj.gov.br/ceep/pib/pib.html. Acesso em: 8 nov. 2015. Gráfico elaborado pelo autor. 
A tendência de expansão econômica no interior e a implantação das atividades produtivas nesse território, resultante da reorientação no influxo de investimentos, contribuíram para um processo de reorganização das taxas de crescimento econômico regional, haja vista que, entre 2000-2012 a porção interiorana do estado do Rio de Janeiro aumentou sua participação na economia estadual de 13,5\% para 25,6\%, enquanto a RMRJ assistiu à diminuição de sua participação de $74 \%$ em 2000 para $61 \%$ em 2012. Nesse período, as regióes do interior do estado, como o Norte Fluminense e as Baixadas Litorâneas, apresentaram os maiores percentuais de crescimento, ampliando sua contribuição no PIB fluminense (Tabela 1).

Tabela 1. Estado do Rio de Janeiro: PIB por regiōes de governo (\%) (2000-2012)

\begin{tabular}{|l|c|l|c|c|}
\hline $\begin{array}{l}\text { Regióes de governo } \\
(\mathbf{2 0 0 0})\end{array}$ & $\mathbf{\%}$ & $\begin{array}{l}\text { Regióes de governo } \\
(\mathbf{2 0 1 2})\end{array}$ & $\mathbf{\%}$ & Variação \% \\
\hline Metropolitana & 74,38 & Metropolitana & 60,84 & $-13,54$ \\
\hline Norte fluminense & 7,39 & Norte fluminense & 16,06 & 8,67 \\
\hline Médio Paraíba & 6,76 & Médio Paraíba & 5,54 & $-1,22$ \\
\hline Serrana & 4,06 & Serrana & 3,89 & $-0,17$ \\
\hline Baixadas Litorâneas & 3,88 & Baixadas Litorâneas & 8,35 & 4,47 \\
\hline Centro-Sul Fluminense & 1,21 & Centro-Sul Fluminense & 1,31 & 0,1 \\
\hline Noroeste Fluminense & 1,23 & Noroeste Fluminense & 1,02 & $-0,21$ \\
\hline Costa Verde & 1,10 & Costa Verde & 2,98 & 1,88 \\
\hline Interior Fluminense & 25,63 & Interior Fluminense & 39,15 & 13,52 \\
\hline
\end{tabular}

Fonte: Fundação Ceperj. Disponível em: http://www.ceperj.rj.gov.br/ceep/pib/pib.html. Acesso em: 8 nov. 2015. Tabela elaborada pelo autor com base na participação por atividade econômica e no valor adicionado bruto, segundo as regiōes de governo e os municípios 2000/2012.

Compreende-se, assim, que a reestruturação territorial fluminense caracteriza-se pela retomada do crescimento econômico estadual, ao lado da reconfiguração econômica regional por que passou o interior do estado, em função da reorientação dos investimentos no território com a implantação de novas atividades produtivas capazes de alterar aquela trajetória econômica decadente. Em consequência desse processo, o estado do Rio de Janeiro irrompeu o século XXI desempenhando um novo papel no cenário econômico nacional.

Nos últimos anos, o estado vem aumentando sua participação na economia brasileira e, isoladamente, respondeu por aproximadamente $12 \%$ do PIB nacional. Superado apenas pelo estado de São Paulo (32\%) e seguido por Minas Gerais (9\%) no que tange à participação na economia nacional, ${ }^{3}$ atualmente o território fluminense se mantém como a segunda maior economia entre as

\footnotetext{
${ }^{3}$ Fundação Ceperj. Disponível em: http://www.ceperj.rj.gov.br/ceep/ceep.html. Acesso em: 20 mar. 2015.
} 
unidades federativas, sendo marcado por um forte influxo de capitais produtivos. É esse aspecto que nos chama a atenção, visto que, diante de uma nova conjuntura econômica conformada por seu processo de reestruturação territorial, o estado do Rio de Janeiro destacou-se na carteira de investimentos industriais, logísticos e de serviços (Terra et al., 2012).

Esse processo de ampliação do influxo de investimentos, sobretudo aquele promovido pela inserção de capitais estrangeiros, evidencia a transnacionalização do território e sua constituição como um espaço nacional da economia internacional (Santos, 1996; Santos e Silveira, 2008). Assim, no sentido de preencher uma lacuna no que concerne ao influxo de investimentos internacionais no estado do Rio de Janeiro, é preciso destacar o processo de inserção dos investimentos chineses no território fluminense.

O fato é que a presença desses investimentos no território fluminense contribui para a continuidade de suas transformaçôes econômico-produtivas, evidenciando sua maior inserção na economia globalizada. Embora tragam contribuiçōes importantes em relação à retomada do crescimento econômico do estado do Rio de Janeiro e evidenciem a reestruturação produtiva do território nas últimas duas décadas, os estudos em geral que avaliam a trajetória econômica fluminense na passagem para o século XXI dão pouca ênfase ao influxo dos investimentos chineses no território fluminense no início do século XXI, sobretudo no período de 2010 a 2013.

Sob a ótica da Geografia, esses investimentos são compreendidos como uma nova territorialidade, com a presença de novos atores no processo de reestruturação territorial fluminense, por se tratar de um grupo de empresas estatais chinesas que, ao serem implantadas no território, atuam segundo a lógica do projeto estratégico nacional de capitalismo de Estado oriental, sendo orientadas pelo interesse em controlar novas áreas e recursos, com vistas à manutenção das taxas de crescimento da República Popular da China. Assim, seguindo a lógica do projeto nacional do governo chinês, no início do século XXI houve uma ampliação dos investimentos chineses no Brasil. Com efeito, o período de 2007 a 2013 totalizou US\$28,3 bilhōes desses investimentos confirmados em nosso país (Tabela 2).

Tabela 2. IED chineses confirmados no Brasil entre 2007-2013

\begin{tabular}{|l|l|}
\hline Ano & Valor total em US\$ \\
\hline 2007 & $434.000 .000,00$ \\
\hline 2008 & $20.000 .000,00$ \\
\hline 2009 & $95.000 .000,00$ \\
\hline 2010 & $13.090 .000 .000,00$ \\
\hline 2011 & $8.030 .000 .000,00$ \\
\hline 2012 & $3.449 .000 .000,00$ \\
\hline 2013 & $3.235 .000 .000,00$ \\
\hline Total & $28.353 .000 .000,00$ \\
\hline
\end{tabular}

Fonte: CEBC (2013) e CEBC (2014 e 2015). Tabela elaborada pelo autor.

A inclusão do estado do Rio de Janeiro nesse processo decorreu da participação do capital sínico em alguns setores produtivos da economia fluminense, incluindo o estado nas áreas compreendidas pela expansão dos investimentos daquele país asiático. A espacialização desses investimentos no 
território nacional caracteriza-se por sua concentração na Região Sudeste do país. Ocupando posição de destaque entre as unidades federativas dessa região, entre 2010 e 2013 o estado do Rio de Janeiro projetou-se como um importante receptor dos investimentos chineses, com um influxo de aproximadamente US\$ 18,8 bilhôes desse tipo de investimento (Tabela 3).

Tabela 3. Investimentos chineses no território fluminense: 2010-2013

\begin{tabular}{|l|l|}
\hline Ano & Valor total em US\$ \\
\hline 2010 & $7.109 .000 .000,00$ \\
\hline 2010 & $3.070 .000 .000,00$ \\
\hline 2010 & $20.000 .000,00$ \\
\hline 2010 & $3.500 .000 .000,00$ \\
\hline 2011 & $200.000 .000,00$ \\
\hline 2011 & $3.500 .000 .000,00$ \\
\hline 2013 & $1.500 .000 .000,00$ \\
\hline Total & $18.899 .000 .000,00$ \\
\hline
\end{tabular}

Fonte: Oliveira, A. (2012) e CEBC (2013; 2014; 2015). Tabela elaborada pelo autor.

Esse volume de capital que ingressa no território corresponde a sete projetos da República Popular da China no estado do Rio de Janeiro, especialmente nos setores automotivo, ferroviário, siderúrgico e energético (petróleo e gás). Problematizar o influxo desse tipo de capital nos territórios nacional e fluminense nos exige compreender a abertura econômica e a projeção da República Popular $\mathrm{da}$ China como investidor internacional.

\section{República Popular da China: abertura econômica e projeção como investidor internacional}

A transferência do epicentro da economia política global da América do Norte para a Ásia Oriental, onde a República Popular da China se projeta como novo líder do renascimento econômico asiático, coloca em evidência a constituição de um novo regime e a conformação de um novo ciclo sistêmico de acumulação (Arrighi, 2008; 2012). A espetacular projeção econômica chinesa é entendida, na perspectiva de Gonçalves (2010), como parte das mudanças estruturais pelas quais o sistema internacional passa.

A retomada econômica do país asiático resulta de uma longa trajetória de expansão material articulada desde o período de fundação da República Popular da China, em condições estruturais es- 


\section{Os investimentos externos diretos da República Popular da China no território fluminense}

pecíficas e empreendendo um esforço de planejamento estatal, com a adoção de uma série de medidas voltadas à expansão econômica, principalmente pela via da industrialização (Ribeiro, 2013).

Localizada na porção oriental da Ásia, a República Popular da China é composta por 34 divisões administrativas ${ }^{4}$ e apresenta uma configuração territorial de 9,6 milhões de $\mathrm{km}^{2}$, estabelecendo limite com mais de uma dezena de Estados-nacionais. Com tamanha extensão, o país mais populoso do mundo (1,3 bilhão de habitantes) não carece de recursos, mas o ritmo de crescimento econômico imposto pelo novo ciclo de expansão da República Popular da China lhe conduziu, desde a década de 1990, a uma perda da autossuficiência em recursos energéticos, como petróleo, gás natural e carvão mineral, entre outros (Ribeiro, 2013).

A partir da última década, quando o país entrou nesse ciclo de expansão baseado nos investimentos em infraestrutura e na indústria pesada, suas reservas de fontes minerais aproximaram-se do limite. Como uma forma de solucionar essas demandas, a China vem direcionando seus investimentos externos diretos para diferentes regiōes ao promover a atuação de empresas estatais para além de suas fronteiras, em busca desses recursos em outros territórios.

Antes de se voltar a atenção para os investimentos diretos chineses no exterior, é preciso assinalar que o país asiático teve de aguardar a Revolução Chinesa de 1949 para romper com o século da humilhação, o período de dominação estrangeira, e somente então, instituir a República Popular, entendendo que as profundas transformações econômicas no território chinês viriam com sua abertura ao influxo de capitais estrangeiros no final na década de 1970. Nesse período, a chegada do governo Deng Xiaoping (1978-1992) foi marcada por importantes reformas que conduziram a trajetória de crescimento econômico na China. Gonçalves (2010) assinala que, desde que Xiaoping deu início à reforma econômica, em 1978, a China aumentou seu PIB numa média anual superior a 10\%. Portanto, contribuíram para esse processo as mudanças na política externa ${ }^{5}$ do país, o que lhe conferiu maior projeção internacional, assim como a modernização das estruturas produtivas, com o programa das Quatro Modernizaçóes ${ }^{6}$ e a abertura econômica aos investimentos estrangeiros.

A abertura econômica ocorrida no final da década de 1970 foi um ponto de inflexão na história econômica do país. Na ocasião, o território da República Popular tornou-se viável à instalação de atividades produtivas e à ampliação e à reprodução do capital excedente das grandes corporações, que encontraram, nas vantagens locacionais oferecidas pelo país, um ambiente favorável à reprodução do capital. Assim, as reformas viabilizaram o ingresso de investimentos internacionais nas zonas especiais do território, possibilitando que a taxa de investimento no PIB atingisse aproximadamente 47\%.

\footnotetext{
${ }^{4}$ As divisōes administrativas da República Popular da China compreendem 23 províncias, cinco regiōes autônomas, quatro municípios centrais e duas regiôes administrativas especiais (Hong Kong e Macau). Disponível em: http://portuguese.cri.cn/chinaabc/chapter1/chapter10202.htm. Acesso em: 23 jul. 2015.

5 "Desde então, a política exterior e o modelo de desenvolvimento foram se adaptando ao propósito de promover desenvolvimento interno, ao estilo cada vez mais próximo da modernização alcançada pelo sistema capitalista de produção, consumo e inserção internacional” (Cervo, 2008, p. 278).

6 O programa das Quatro Modernizações da China compreendeu a modernização dos setores de agricultura, indústria, tecnologia e defesa nacional (Kissinger, 2011).
} 
Nos anos 1980, com a promoção de uma política de abertura do território ao capital estrangeiro, a República Popular da China vivenciou um grande influxo de investimentos externos e, a partir da década de 1990, o país asiático alterou sua política de recepção de IDE, abrindo o mercado às empresas estrangeiras ligadas aos setores de serviços de telecomunicaçōes, bancos, seguros e tecnologia avançada, exigindo-se, então, a formação de joint ventures com empresas locais sob o controle estatal. Nesse sentido, com o objetivo de atenuar as desigualdades regionais, o governo chinês adotou, a partir de 1997, políticas de atração de investimentos estrangeiros nas regiōes central e ocidental do país, estendendo a política de abertura a todas as capitais provinciais, às regiōes autônomas e a algumas cidades fronteiriças, o que tornava as ZEEs "menos especiais" ao influxo do capital estrangeiro (Alves, 2014).

Como resultado desse processo, manteve-se crescente o influxo de IED no território chinês entre aquela década e o início do século XXI, o que tornou a República Popular da China um importante país para os investidores internacionais. Assim, o país saltou na recepção de investimentos estrangeiros, de US\$ 1,4 bilhão em 1984 para US \$ 37,5 bilhões em 1995, atingindo US\$ 111,7 bilhōes em 2012 (Gráfico 5).

Gráfico 5. República Popular da China: influxo de IED - 1984-2012

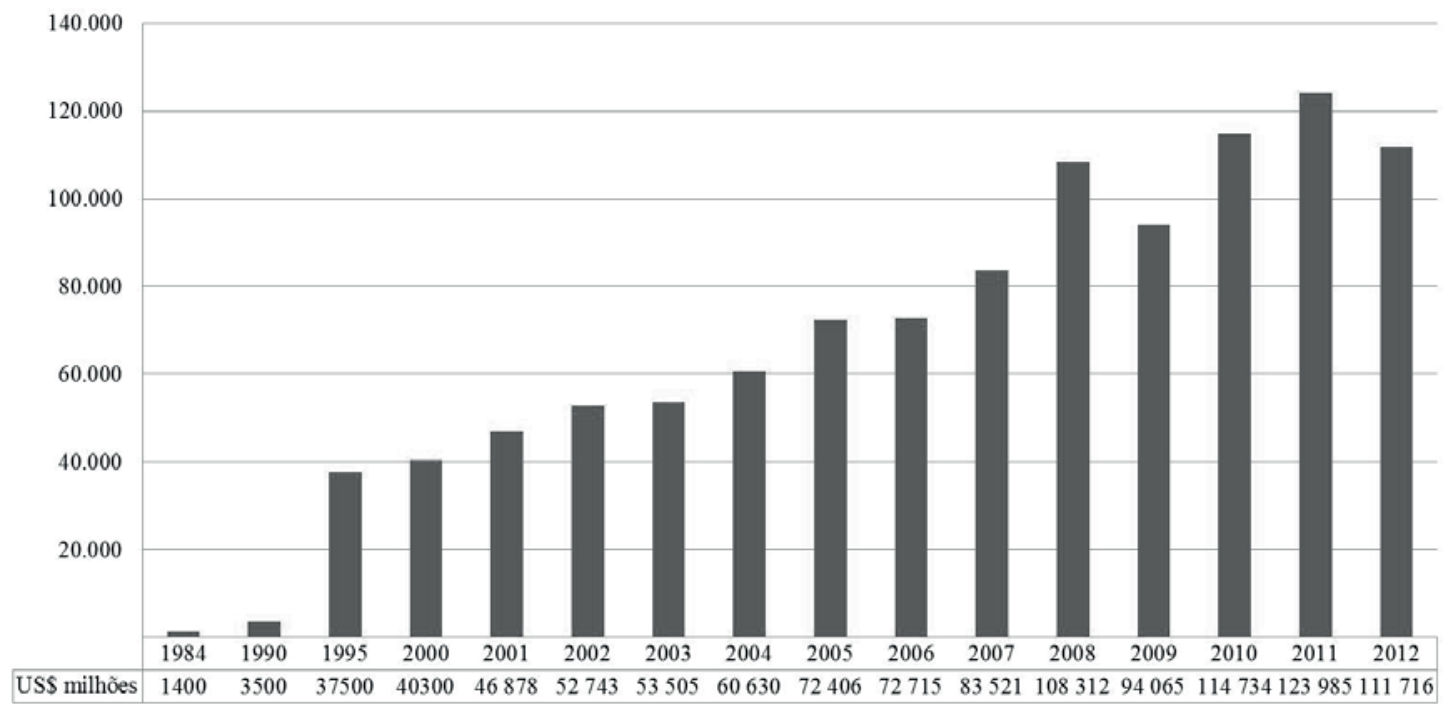

Fonte: Chinability (s.d.) e UNCTAD (s.d.). Disponível em: http://unctad.org/Sections/dite_fdistat/docs/webdiaeia2014d3_CHN.pdf. Acesso em 8 nov. 2015. Disponível em: http://www.chinability.com/FDI.htm. Acesso em: 8 nov. 2015. Gráfico elaborado pelo autor.

Nesse contexto, nas últimas décadas a China projetou-se como um país asiático receptor de investimentos externos diretos estrangeiros, mantendo suas taxas de crescimento econômico bastante elevadas. No entanto, desde o final do século XX, a República Popular da China coloca em prática um conjunto de iniciativas para expandir seus investimentos no exterior e vivencia diferentes fases no processo de evolução de sua política para a saída desses investimentos. Assim, o país alçou à posição de maior investidor internacional entre os países de sua região no início do século XXI. Porém, como bem 
apontado por Buckley et al. (2010) e Oliveira (2012), pouca tem sido a atenção dispensada à República Popular da China como investidor internacional.

Além da projeção como recipiendária de investimentos, a República Popular da China ampliou sua participação no estoque e no fluxo de investimentos em todo o mundo, apresentando trajetória ascensional na condição de investidor internacional. Esse processo despertou a atenção mundial e motivou a realização de pesquisas para identificar a passagem do país da condição de grande receptor de investimentos à de investidor internacional. Entre essas pesquisas, têm-se as realizadas por Buckley et al. (2010), Ribeiro (2010; 2013), Ipea (2011), Oliveira (2012), CEBC (2011; 2013) e Alves (2014).?

Embora a internacionalização dos investimentos chineses já viesse ocorrendo desde 1979 - quando das primeiras concessōes para realizar investimentos no exterior, foi somente a partir da década de 1990 que aquele país ampliou sua participação no fluxo e no estoque de IED no mundo (Buckley et al., 2010; Oliveira, 2012; CEBC, 2013; Alves, 2014). Com efeito, a República Popular da China manteve sua trajetória de ampliação dos investimentos no exterior e, em 2012, atingiu US \$ 531,9 bilhôes em seus estoques de investimentos externos, chegando, em 2014, a US\$ 116 bilhões em fluxos de investimento no exterior (Gráficos 6 e 7).

Gráfico 6. República Popular da China: estoque de investimento direto no exterior entre 1990-2012

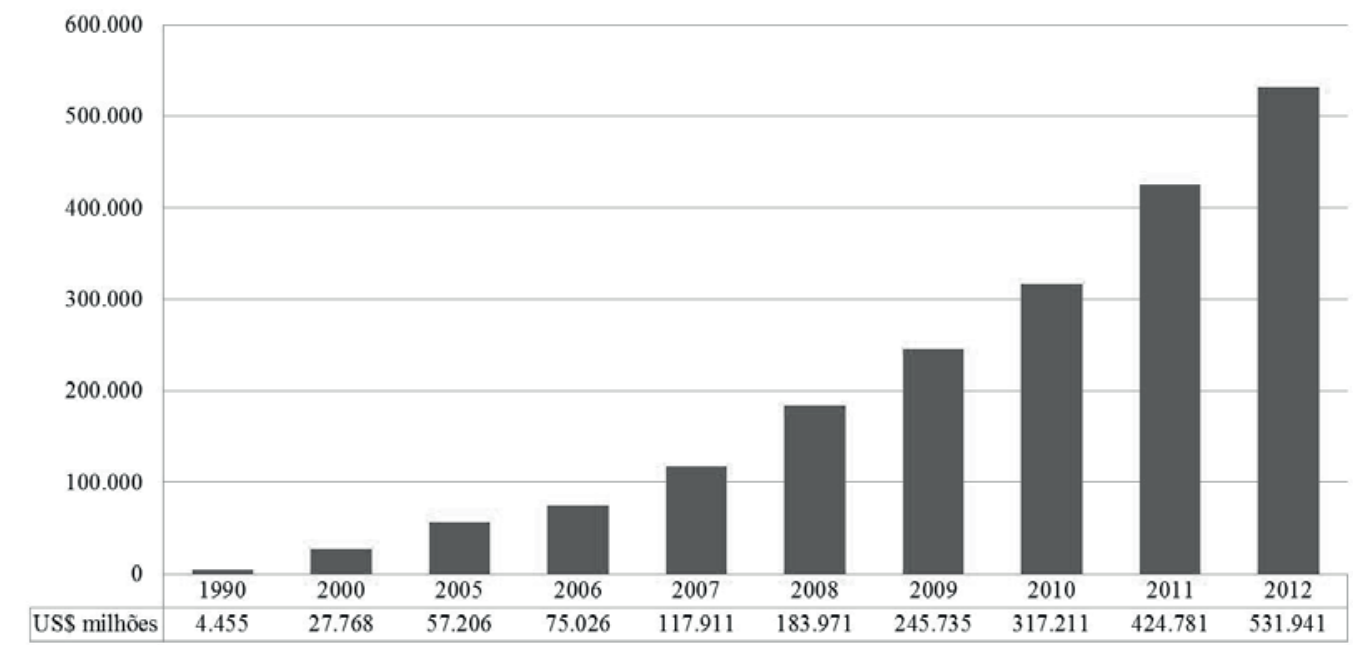

Fonte: Alves (2014) e UNCTAD (s.d.). Disponível em: http://unctad.org/Sections/dite_fdistat/docs/webdiaeia2014d3_ CHN.pdf. Acesso em 8 nov. 2015. Gráfico elaborado pelo autor.

\footnotetext{
7 Muitos estudos abordaram essa temática, em face de sua relevância para a dinâmica daquela economia asiática e também para a economia mundial. Alguns deles são aqui retomados, por representarem referências teóricas acerca da expansão dos investimentos chineses no mundo, subsidiando nossa análise sobre a ascensão da China como investidor internacional.
} 
Gráfico 7. República Popular da China: fluxo de investimentos diretos para o exterior entre 2000-2014

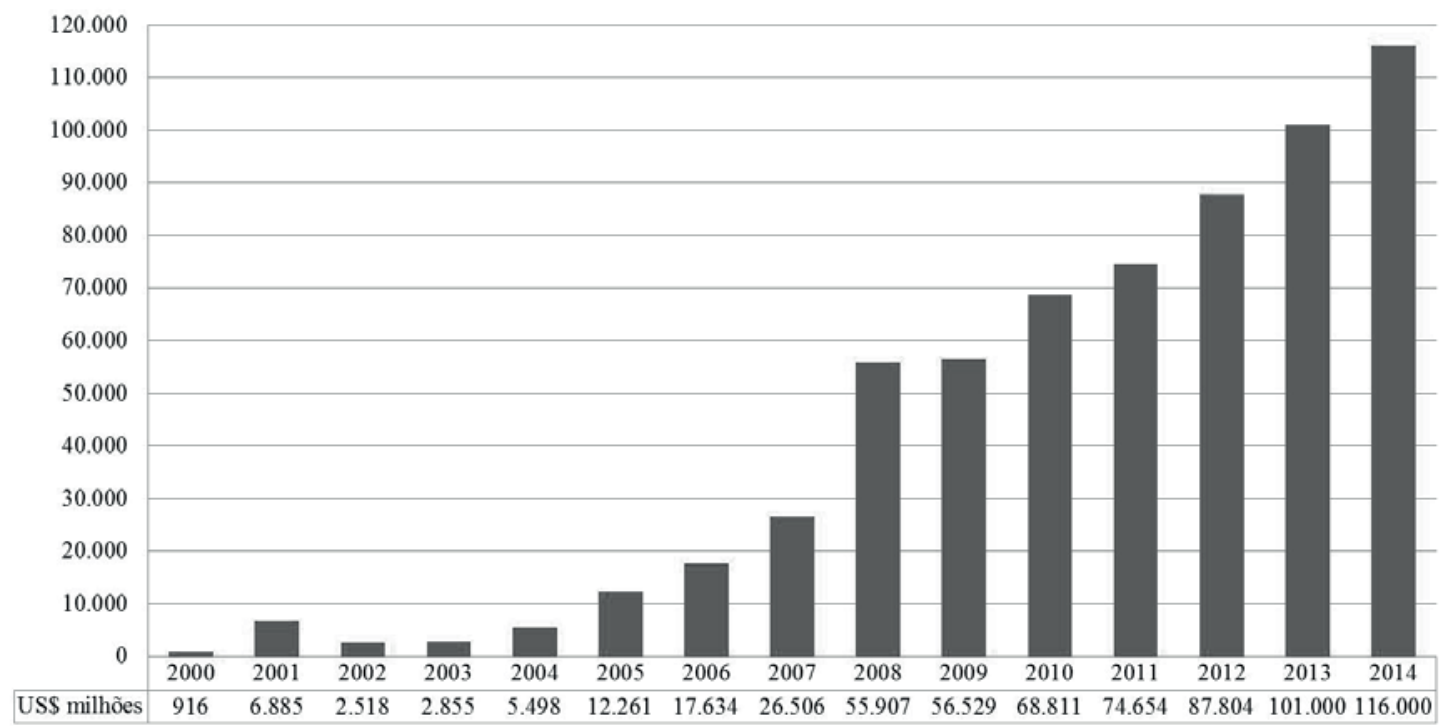

Fonte: Alves (2014); Chinability (s.d.) e UNCTAD (s.d.). Disponível em: http://www.chinability.com/ODI.htm. Acesso em: 8 nov. 2015. Disponível em: http://unctad.org/Sections/dite_fdistat/docs/webdiaeia2014d3_CHN.pdf. Acesso em 8 nov. 2015. Gráfico elaborado pelo autor.

O desempenho alcançado como investidor internacional pela República Popular da China remonta a uma trajetória gradual de expansão de seus investimentos no exterior, dotando-a de capacidade político-econômica para investir em diferentes regiōes do mundo com assertividade e pragmatismo. Assim, a influência do país asiático foi ampliada não pela via da coação, mas por relações econômicas e aumento de seus investimentos nos países em desenvolvimento e nas economias detentoras de recursos.

Oliveira (2012) e CEBC (2013) tomam Buckley et al. (2007; 2010) como referencial para abordar as políticas de desenvolvimento do IED chinês. Seguindo a divisão proposta por esses autores acerca da liberalização dos investimentos chineses no exterior, compreende-se a divisão de cinco estágios de expansão, denominados internacionalização cautelosa, encorajamento governamental, regulação e expansão, Go Global e periodo pós-OMC. Alves (2014), contudo, divide o processo de expansão dos investimentos chineses no exterior em três fases, cujos agrupamento e classificação são compreendidos pelos recortes temporais 1979-1991, 1992-2000 e 2001-até a presente data. Nos quadros 1 e 2, expõem-se, de maneira sucinta, as principais considerações acerca desses estágios e/ou fases de expansão dos IED chineses no exterior. 
Quadro 1. Esquema-síntese do modelo de expansão dos investimentos chineses no exterior segundo Buckley (2010), Oliveira (2012) e CEBC (2013)

\begin{tabular}{|c|c|c|c|c|}
\hline \multicolumn{5}{|c|}{ Estágios de expansão dos IEDs chineses } \\
\hline 1 o Estágio & 2o Estágio & 3o Estágio & $4^{0}$ Estágio & 50 Estágio \\
\hline $\begin{array}{l}\text { Internacio- } \\
\text { - nalização } \\
\text { Cautelosa }\end{array}$ & $\begin{array}{l}\text { Encorajamento Governa- } \\
\text { mental }\end{array}$ & $\begin{array}{l}\text { Regulação e Expan- } \\
\text { são }\end{array}$ & Go Global & Período pós-OMC \\
\hline 1979-1985 & 1986-1991 & 1992-1998 & 1999-2001 & $2001 \ldots$ \\
\hline $\begin{array}{l}\text { Aprimorar o } \\
\text { acesso aos re- } \\
\text { cursos natu- } \\
\text { rais escassos } \\
\text { na China }\end{array}$ & $\begin{array}{l}\text { Estabelecer filiais em outros } \\
\text { países, cujos objetivos com- } \\
\text { preendiam: apoiar a função } \\
\text { exportadora das grandes fá- } \\
\text { bricas estatais; ajudar a estabi- } \\
\text { lizar a demanda por recursos } \\
\text { naturais; adquirir informação } \\
\text { e aprender como operar no } \\
\text { exterior }\end{array}$ & $\begin{array}{l}\text { Expansão e regu- } \\
\text { lação das empresas } \\
\text { chinesas, investi- } \\
\text { mentos e ações em } \\
\text { bens imobiliários }\end{array}$ & $\begin{array}{l}\text { Explorar novos merca- } \\
\text { dos para seus produ- } \\
\text { tos; melhorar o acesso à } \\
\text { propriedade tecnológica } \\
\text { estrangeira; aprimorar a } \\
\text { competitividade chinesa } \\
\text { por meio da diversifi- } \\
\text { cação de atividades de } \\
\text { negócios realizadas no } \\
\text { exterior }\end{array}$ & $\begin{array}{l}\text { Caracteriza-se pelo } \\
\text { afrouxamento dos } \\
\text { mecanismos de con- } \\
\text { trole do investimento } \\
\text { no exterior }\end{array}$ \\
\hline
\end{tabular}

Fonte: Quadro elaborado pelo autor.

Quadro 2. Esquema-síntese do modelo de expansão dos investimentos chineses no exterior segundo Alves (2012)

Fases de expansão dos IEDs

\begin{tabular}{|c|c|}
\hline $1^{a}$ Fase (1979-1991) & 2a Fase (1992-2000) \\
\hline $\begin{array}{l}\text { Passos iniciais para a internacionalização das } \\
\text { empresas chinesas, com o objetivo de importar } \\
\text { tecnologia e equipamentos avançados, promo- } \\
\text { ver fontes confiáveis de recursos naturais estra- } \\
\text { tégicos para o desenvolvimento chinês, gerar } \\
\text { divisas para a China e auxiliar na exportação } \\
\text { de bens e serviços }\end{array}$ & $\begin{array}{l}\text { Política de encorajamento do } \\
\text { presas estatais. Saída de IDE cc } \\
\text { i) focar no uso de tecnologias; } \\
\text { ii) obtenção de recursos e } \\
\text { iii) mercados estratégicos }\end{array}$ \\
\hline
\end{tabular}

\section{3a Fase 2001-até a presente data (Go Global)}

Inserção competitiva das empresas chinesas no mercado globalizado, com o objetivo de:

i) elevar a competitividade e ampliar a cooperação econômica e técnica internacional da China;

ii) cooperar com a provisão de mão de obra em outros países; encorajar algumas empresas a explorarem o processamento

e o comércio no exterior; e contribuir para a exportação de produtos, serviços e tecnologias da China;

iii) apoiar a exploração além-mar dos recursos naturais domesticamente escassos;

iv) estabelecer centros de P\&D nos países receptores;

v) desenvolver operaçóes transnacionais;

vi) estabelecer um ambiente satisfatório de investimento no exterior;

vii) aperfeiçoar os mecanismos regulatórios internos voltados à regulação e à supervisão dos investimentos no exterior (Wenbin e Wilkes apud Alves, 2014, p. 352).

Fonte: Quadro elaborado pelo autor. 
Mudando com a maneira planejada de lidar com os investimentos no exterior, instituída desde o final da década de 1970, compreende-se que a estratégia Go Global conduziu a República Popular da China a uma posição de investidor internacional. Desde então, o país asiático aumentou sua participação nos fluxos e estoques de IDE no exterior. Com efeito, "a China ultrapassou o Japão para se tornar a quinta maior fonte global de investimentos em 2010” (CEBC, 2013, p. 23). ${ }^{8}$ Em 2011,

a política Go Global foi reiterada no $12^{\circ}$ plano quinquenal, com provisões para: aperfeiçoar o mecanismo de coordenação geral intersetorial, a fim de fortalecer a implementação da estratégia Go Global, e oferecer macro-orientaçôes às empresas; melhorar o sistema de leis e regulamentos para o investimento estrangeiro e evitar a dupla tributação; negociar acordos bilaterais de investimentos; desenvolver o sistema internacional de recursos energéticos; , e fornecer apoio para os investimentos em Pesquisa e Desenvolvimento (P\&D) no exterior (CEBC, 2013, pp. 26-7).

Segundo CEBC (2013), as novas diretrizes de IED retratam algumas mudanças político-econômicas chinesas, promovem maior integração do país na economia mundial e atendem a alguns objetivos específicos, como, por exemplo, permitir que as empresas chinesas garantam suprimento de energia e matéria-prima no longo prazo, com o acesso a mercados estrangeiros. Embora tracem diferentes propostas temporais de classificação sobre a expansão dos investimentos chineses no mundo, bem como apresentem dados com ligeiras diferenças quantitativas em relação aos apresentados pela Unctad (2014), ${ }^{9}$ as consideraçōes de Jabbour (2010), Buckley et al. (2010), Oliveira (2012), Ipea (2011), CEBC (2013) e Alves (2014) convergem e nos auxiliam na compreensão da China como investidor internacional.

Portanto, há que se salientar que, mesmo mudando seus objetivos ao ampliar seus investimentos no exterior, nota-se que, desde o início da internacionalização de seus investimentos, a República Popular da China teve a intenção de garantir acesso ao suprimento de recursos necessários ao seu desenvolvimento. Com esse objetivo, o país asiático deu início à expansão de seus investimentos no exterior, direcionando-os, inicialmente, aos países desenvolvidos. No entanto, recentemente, os maiores receptores dos investimentos chineses são os países em desenvolvimento situados na Ásia, na América Latina e na África, o que evidencia uma reorganização geográfica na distribuição espacial dos investimentos chineses, temática contemplada nas linhas subsequentes.

A distribuição dos investimentos chineses por região revela que os países desenvolvidos ainda estão inclusos na estratégia de internacionalização das empresas chinesas, embora com objetivos distintos, quando comparados àqueles destinados às regiões compreendidas pelas economias em desenvolvimento. No início do século XXI, os países em desenvolvimento tiveram sua participação consideravelmente ampliada no fluxo e no estoque de investimentos chineses e, entre 2003 e 2012, a

\footnotetext{
8 Antecedida apenas por França, Hong Kong, Alemanha e Estados Unidos (CEBC, 2013).

9 Em consulta ao site da Unctad, verificou-se que os dados acerca de fluxo e estoque de IDE nos países são continuamente atualizados, o que implica algumas ligeiras diferenças quantitativas para os anos mais recentes, em comparação aos estudos tomados como referência neste estudo.
} 
China direcionou o maior volume de investimentos externos para os países que integram as regiōes da Ásia, da América Latina e do Caribe (Gráficos 8 e 9).

Gráfico 8. República Popular da China: distribuição geográfica dos fluxos de investimentos externos diretos chineses, por regiões entre 2003-2012 (em US\$ milhões)

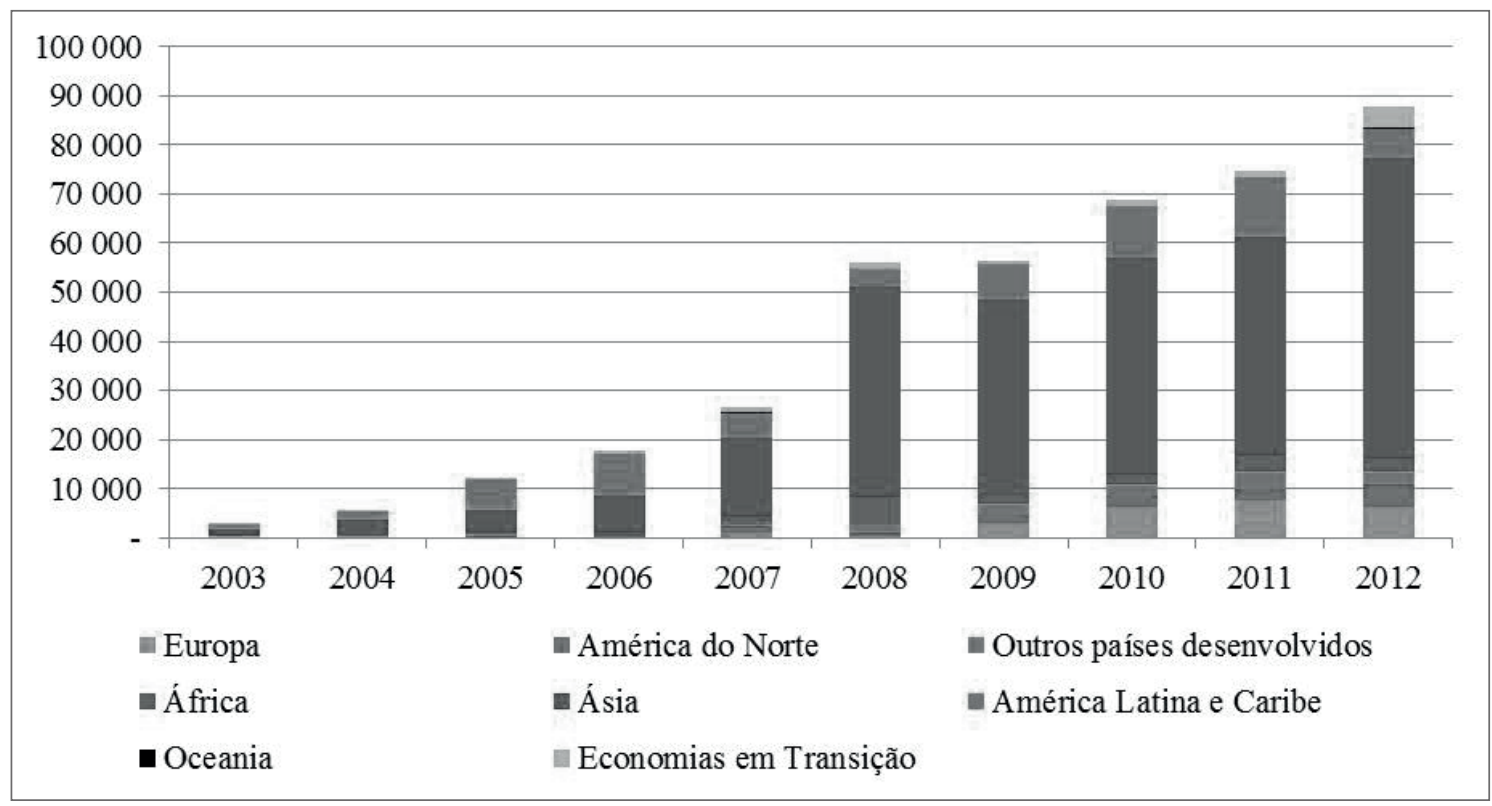

Fonte: Unctad (s.d.). Disponível em: http://unctad.org/Sections/dite_fdistat/docs/webdiaeia2014d3_CHN.pdf. Acesso em: 8 nov. 2015. Gráfico elaborado pelo autor.

Nesse contexto, os estoques de investimentos chineses no exterior tornaram-se maiores nas regiôes compostas pelas economias em desenvolvimento, o que levou a Ásia, a América Latina e o Caribe a se projetarem como as regiões que apresentaram maior estoque de IED chinês. Seguindo essa tendência, também na África, o estoque de investimentos chineses foi ampliado. Em contrapartida, as regióes que formam as economias desenvolvidas, embora tenham mantido os estoques de IDE, estes não foram tão volumosos quanto se mostraram até os anos 1990 (Gráfico 9). 
Gráfico 9. República Popular da China: distribuição geográfica dos estoques de investimentos externos diretos chineses por regiões (2003-2012, em US\$ milhões)

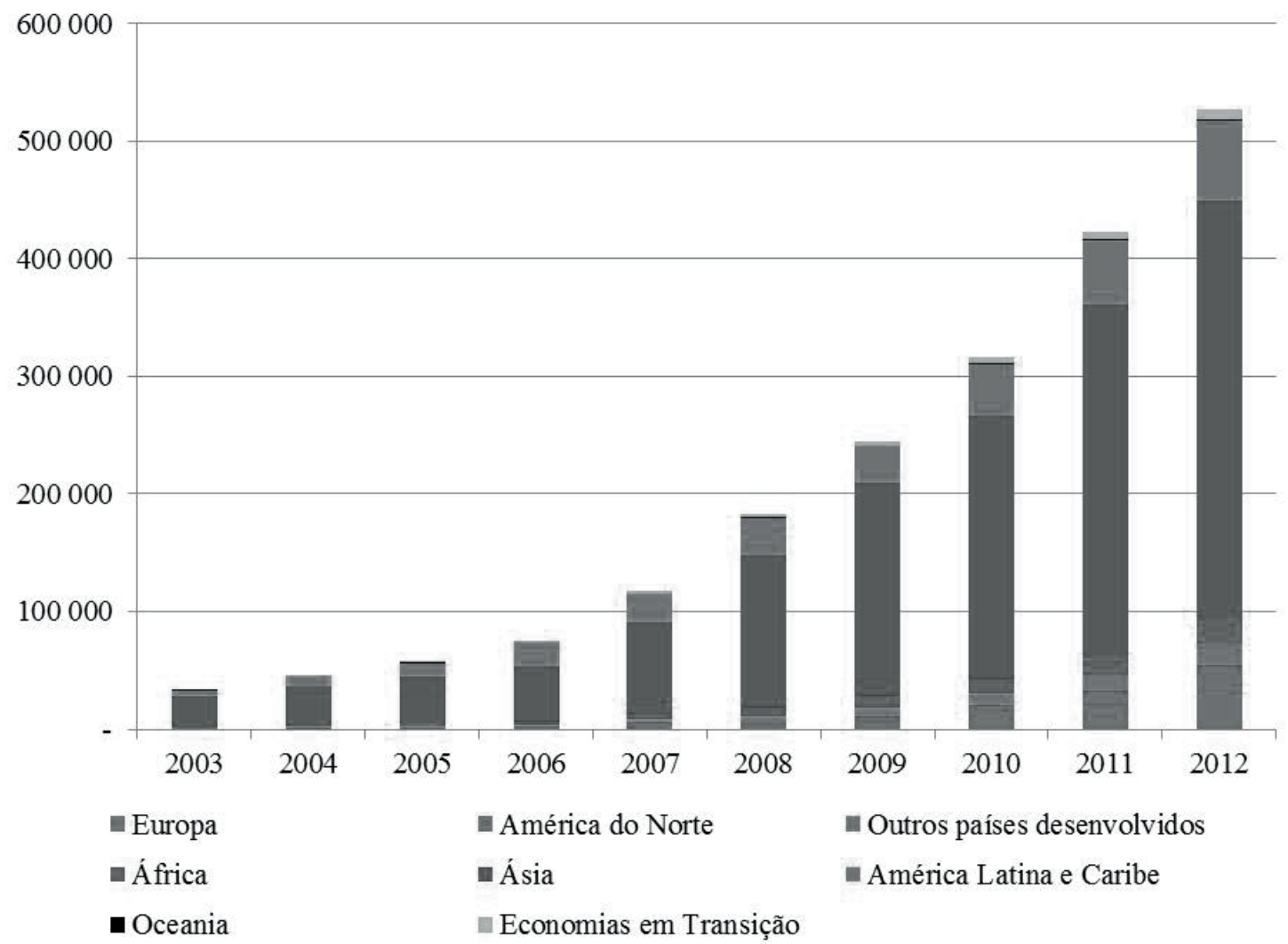

Fonte: Unctad (s.d.). Disponível em: http://unctad.org/Sections/dite_fdistat/docs/webdiaeia2014d3_CHN.pdf. Acesso em: 8 nov. 2015. Gráfico elaborado pelo autor.

A América Latina é uma região em que a presença chinesa torna-se crescente, tanto pelo ingresso de produtos importados desse país quanto pelo incremento dos investimentos no presente século. No que diz respeito aos investimentos chineses nesse recorte regional, observa-se que ocupa a posição de segundo maior receptor desses investimentos, em virtude do incremento no fluxo entre 2003-2012 - de US\$ 1 bilhão em 2003 para US\$11,9 bilhões em 2011, apresentando uma queda em 2012 para US\$ 6,1 bilhões. Por outro lado, o salto de US\$ 4,6 bilhões em 2003 para US\$ 68,2 bilhões em 2012 em relação ao estoque desse tipo de investimento - o que representa cerca de 13\% do estoque de investimento direto no exterior daquele país - leva-nos a concordar com Sutter (2010), quando aponta que, por meio de seus investimentos, a China amplia seu papel de atuação na região.

Anuímos com Gonçalves (2010) quando aponta que a China passou a interagir com mais atores do sistema internacional, expandindo suas relaçôes bilaterais com um número maior de países e criando fortes laços de interdependência com os países de todos os continentes. Também con- 
cordamos com Ribeiro (2013), no sentido de que o governo chinês, através das empresas estatais, vem promovendo diversas abordagens em regiōes que dispõem de amplos recursos naturais, como África e América Latina. Em verdade, o interesse chinês no acesso a recursos primários e energéticos vem motivando seu estímulo à importação e à expansão de investimentos diretos em diversos países dessas duas regiōes. Boniface e Védrine (2009), ao analisarem "o mundo visto pela China" (Figura 2), espacializam o interesse chinês em diferentes regióes do mundo e destacam que esse país asiático "interessa-se hoje [...] pela América Latina, para garantir a energia e as matérias-primas que lhe faltam" (p. 97).

Figura 2. O mundo visto pela China. Municípios receptores de investimentos chineses

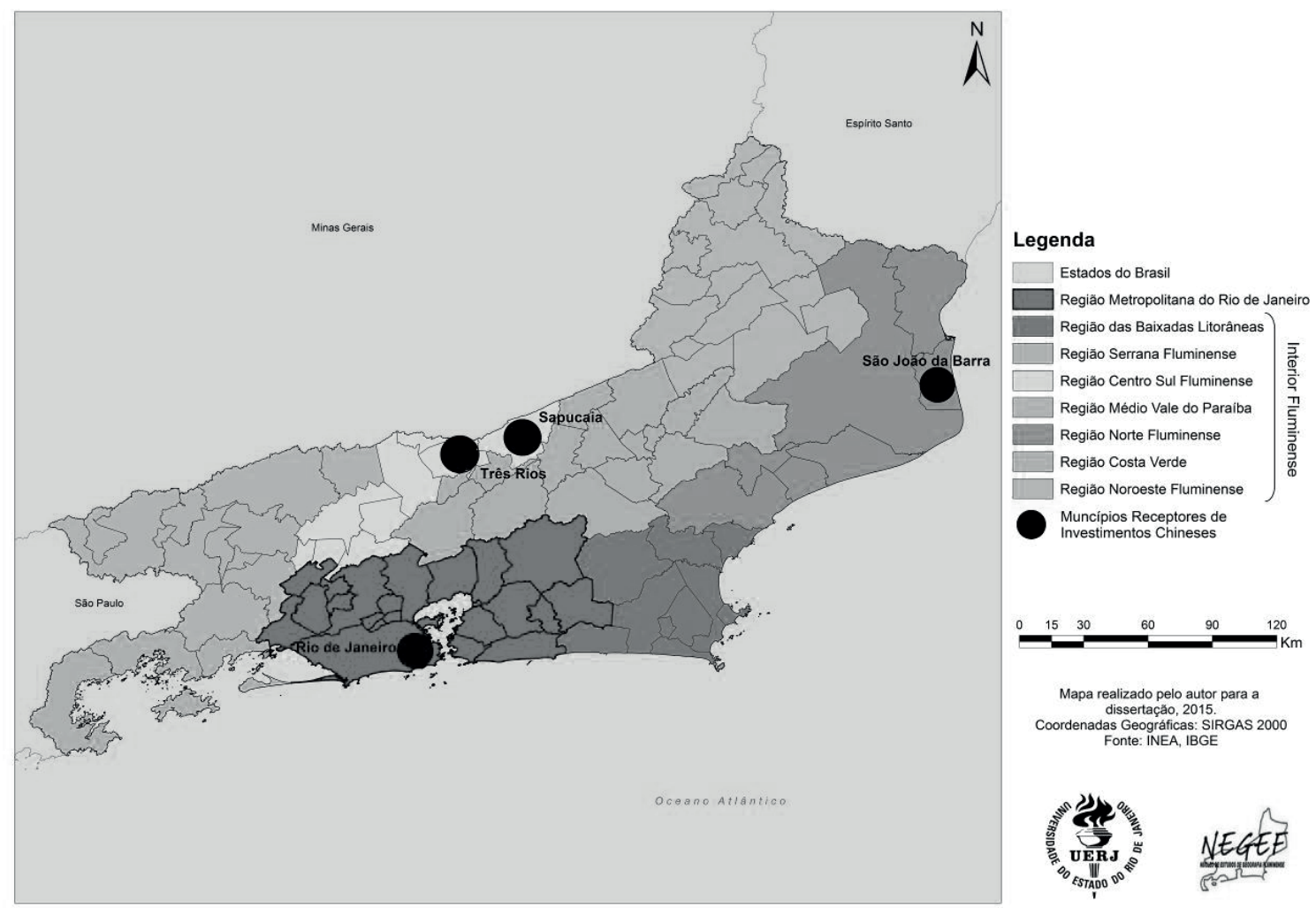

Fonte: Boniface e Védrine (2009).

Assim, América Latina afirma-se como uma região de complementaridade à República Popular da China, por causa da busca pelo acesso a matérias-primas via investimentos. $\mathrm{O}$ interesse chinês volta-se para a aquisição de recursos estratégicos como petróleo, cobre e ferro, a fim de suprir sua demanda interna, tendo o país realizado ainda investimentos na montagem de manufaturados, telecomunicações e têxtil (Ipea, 2011; Oliveira, 2012). Assim como ocorre em relação a outros países da região, o interesse chinês pelo Brasil tem fundamento na busca por novos mercados e recursos, 
sobretudo minério de ferro, soja e petróleo, produtos que ocupam posição de destaque na pauta das exportações brasileiras para aquela economia asiática.

\section{Investimentos chineses no território fluminense no século XXI (2010-2013)}

O ano de 2010 consolidou-se como um marco para o recebimento de investimentos chineses no território brasileiro. Embora já estivessem presentes no período de 2007 a 2009, o influxo de investimentos chineses confirmados no Brasil foi baixo, somando US\$ 549 milhôes. Entretanto, de 2010 em diante, o influxo desses investimentos foi ampliado no território, em face da confirmação do ingresso de US\$ 13 bilhões, sucedidos, nos anos subsequentes, por outros influxos confirmados, como US\$ 8 bilhōes em 2011, US\$ 3,4 bilhões em 2012 e US\$ 3,2 bilhōes em $2013 .^{10}$

Na Região Sudeste, o estado do Rio de Janeiro destacou-se como um dos maiores receptores de capital sínico, com o influxo de US\$18,8 bilhóes entre 2010-2013. Na Tabela 4, apresenta-se o volume de capital investido pela China no território fluminense nesse período, bem como as operaçôes das empresas chinesas, seus modos de entrada e setores de atuação.

Tabela 4. Investimentos chineses no território fluminense entre 2010-2013

\begin{tabular}{|c|c|c|c|c|c|c|c|}
\hline Projeto & Ano & $\begin{array}{l}\text { Empresa de } \\
\text { origem }\end{array}$ & $\begin{array}{l}\text { Valor em } \\
\text { US\$ }\end{array}$ & $\begin{array}{l}\text { Modo de } \\
\text { entrada }\end{array}$ & Setor & $\begin{array}{l}\text { Estrutura de } \\
\text { propriedade }\end{array}$ & $\begin{array}{l}\text { Determi- } \\
\text { nante do } \\
\text { investi- } \\
\text { mento }\end{array}$ \\
\hline 1 & 2010 & $\begin{array}{l}\text { Sinopec Repsol } \\
\text { Brasil* } \\
\text { (Confirmado) }\end{array}$ & 7.109 .000 .000 & $\begin{array}{l}\text { Fusões e aquisi- } \\
\text { ções (parciais) }\end{array}$ & $\begin{array}{l}\text { Energia (petró- } \\
\text { leo e gás) }\end{array}$ & Central SOE & $\begin{array}{l}\text { Busca por } \\
\text { Recursos }\end{array}$ \\
\hline 2 & 2010 & $\begin{array}{l}\text { Sinochem Sta- } \\
\text { toil ASA** } \\
\text { (Confirmado) }\end{array}$ & 3.070 .000 .000 & $\begin{array}{l}\text { Fusões e aquisi- } \\
\text { çôes (parciais) }\end{array}$ & $\begin{array}{l}\text { Energia (petró- } \\
\text { leo e gás) }\end{array}$ & Central SOE & $\begin{array}{l}\text { Busca por } \\
\text { recursos }\end{array}$ \\
\hline 3 & 2010 & $\begin{array}{l}\text { CR Zong- } \\
\text {-shen*** } \\
\text { (Confirmado) } \\
\end{array}$ & 20.000 .000 & Greenfield & Automotivo & Privada & $\begin{array}{l}\text { Busca por } \\
\text { mercado }\end{array}$ \\
\hline 4 & 2010 & $\begin{array}{l}\text { Wuhan Iron/ } \\
\text { Stell Group Co. } \\
\text { (Wisco) } \\
* * * * \\
\text { (Confirmado) }\end{array}$ & 3.500 .000 .000 & Joint Venture & Siderurgia & Central SOE & $\begin{array}{l}\text { Busca por } \\
\text { recursos }\end{array}$ \\
\hline
\end{tabular}

${ }^{10}$ Ver Tabela 1. 


\begin{tabular}{|c|c|c|c|c|c|c|c|}
\hline Projeto & Ano & $\begin{array}{l}\text { Empresa de } \\
\text { origem }\end{array}$ & $\begin{array}{l}\text { Valor em } \\
\text { US\$ }\end{array}$ & $\begin{array}{l}\text { Modo de } \\
\text { entrada }\end{array}$ & Setor & $\begin{array}{l}\text { Estrutura de } \\
\text { propriedade }\end{array}$ & $\begin{array}{l}\text { Determi- } \\
\text { nante do } \\
\text { investi- } \\
\text { mento }\end{array}$ \\
\hline 5 & 2011 & $\begin{array}{l}\text { China Northem } \\
\text { Railway } \\
* * * * * \\
\text { (Confirmado) }\end{array}$ & 200.000 .000 & $\begin{array}{l}\text { Fusões e aquisi- } \\
\text { çōes (completas) }\end{array}$ & Ferroviário & SOE & $\begin{array}{l}\text { Busca por } \\
\text { mercado }\end{array}$ \\
\hline 6 & 2011 & $\begin{array}{l}\text { Sinopec } \\
* * * * * * \\
\text { (Confirmado) }\end{array}$ & 3.500 .000 .000 & $\begin{array}{l}\text { Fusões e aquisi- } \\
\text { çōes (parciais) }\end{array}$ & $\begin{array}{l}\text { Energia (petró- } \\
\text { leo e gás) }\end{array}$ & Central SOE & $\begin{array}{l}\text { Busca por } \\
\text { recursos }\end{array}$ \\
\hline 7 & 2013 & $\begin{array}{l}\text { CNPC e } \\
\text { CNOOC } \\
* * * * * * * \\
\text { (Confirmado) } \\
\end{array}$ & 1.500 .000 .000 & $\begin{array}{l}\text { Fusōes e aquisi- } \\
\text { çōes (parciais) }\end{array}$ & $\begin{array}{l}\text { Energia (petró- } \\
\text { leo e gás) }\end{array}$ & Central SOE & $\begin{array}{l}\text { Busca por } \\
\text { recursos }\end{array}$ \\
\hline & Total & & 18.899 .000 .000 & & & & \\
\hline
\end{tabular}

* Compra de 40\% das operaçóes brasileiras da empresa espanhola Repsol (Oliveira, 2012, p. 209).

** Aquisição de 40\% da exploração do campo de petróleo offshore Peregrino (bacia de Campos) (Oliveira, 2012, p. 209).

*** Instalação de fábrica utilizando a marca Kasinski (Oliveira, 2012, p. 210).

**** Instalação de siderúrgica, com $70 \%$ de participação da Wisco na joint venture (Porto do Açu, São João da Barra) (Oliveira, 2012, p. 210).

***** Fabricação de 34 trens para o governo do estado do Rio de Janeiro. O valor será investido na aquisição de maquinário e modernização de planta já existente. A previsão é alcançar 2.500 trabalhadores (Oliveira, 2012, p. 211).

****** 30\% dos ativos da Galp no Brasil (Oliveira, 2012, p. 211).

******* As empresas chinesas CNPC e CNOOC arremataram, em conjunto com a anglo-holandesa Shell, a francesa Total e a brasileira Petrobras, a concessão para exploração de petróleo e gás no Campo de Libra, no pré-sal da bacia de Campos (CEBC, 2014, p. 16).

Fonte: Oliveira (2012) e CEBC (2013, 2014 e 2015). Tabela elaborada pelo autor.

Quando se classificam os investimentos, é possível identificar que, do total dos investimentos direcionados ao território fluminense no mencionado período, 99\% (o equivalente a US\$18,6 bilhôes) dos investimentos chineses têm a busca de recursos como fator determinante. Esse volume de capital corresponde à maior parcela dos investimentos chineses confirmada no território fluminense, sendo sucedido, de longe, pelos US\$ 220 milhôes destinados à busca de mercado, o que corresponde a uma parcela pouco representativa dos investimentos da República Popular no território do estado do Rio de Janeiro (Gráfico 10). 
Gráfico 10. Distribuição dos investimentos chineses no território fluminense em US\$ por determinantes entre 2010-2013

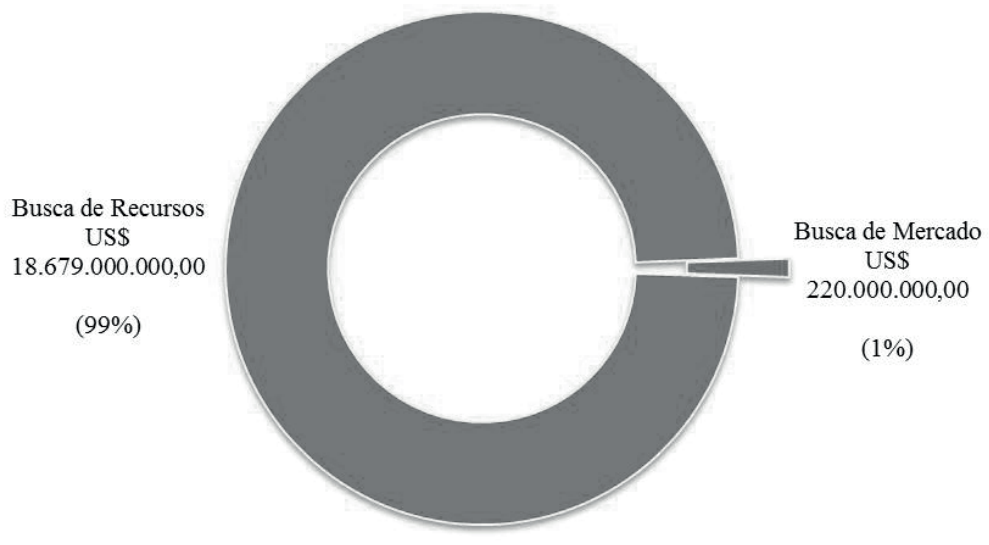

Fonte: Oliveira (2012), CEBC (2013, 2014 e 2015). Gráfico elaborado pelo autor.

A organização dos projetos das empresas chinesas por modo de entrada também possibilita a análise das formas de ingresso desse capital no território fluminense (Tabela 5).

Tabela 5. Formas de ingresso dos investimentos chineses no território fluminense (2010-2013)

\begin{tabular}{|l|l|l|l|l|l|}
\hline $\begin{array}{l}\text { No de } \\
\text { projetos }\end{array}$ & Modo de entrada & Setor & $\begin{array}{l}\text { Estrutura de } \\
\text { propriedade }\end{array}$ & $\begin{array}{l}\text { Determinante do } \\
\text { investimento }\end{array}$ & Valor em US\$ \\
\hline 4 & $\begin{array}{l}\text { Fusóes e Aquisiçōes } \\
\text { (parcial) }\end{array}$ & $\begin{array}{l}\text { Energia (petróleo e } \\
\text { gás) }\end{array}$ & Central SOE & Busca de recursos & 15.179 .000 .000 \\
\hline 1 & $\begin{array}{l}\text { Fusōes e Aquisiçōes } \\
\text { (parciais) }\end{array}$ & Ferroviário & Central SOE & Busca de mercado & 200.000 .000 \\
\hline 1 & Joint-venture & Siderurgia & Central SOE & Busca de recursos & 3.500 .000 .000 \\
\hline 1 & Greenfield & Automotivo & Privada & Busca de mercado & 20.000 .000 \\
\hline 7 & Total & \multicolumn{3}{|l}{} \\
\hline
\end{tabular}

Fonte: Oliveira (2012) e CEBC (2013, 2014 e 2015). Tabela elaborada pelo autor.

A análise da Tabela 5 aponta que os US \$ 18,8 bilhões em investimentos chineses correspondem a sete projetos implementados no território fluminense no período de 2010-2013, concentrando-se no setor de energia (petróleo e gás), em detrimento dos demais setores (ferroviário, siderúrgico e automotivo).

Como assinalado, quando se examina o fator determinante para investimento no projeto, nota-se que grande parte do capital se concentra na busca por recursos, correspondendo a cinco projetos, enquanto a busca por mercado é contemplada por apenas dois projetos. Em consequência desse direcionamento, o setor ferroviário e o setor automotivo contam com apenas um projeto cada, ambos 


\section{Os investimentos externos diretos da República Popular da China no território fluminense}

equivalentes a US\$ 200 milhões (1\%) e US\$ 20 milhões (menos de 1\%), respectivamente. Dos cinco projetos que visam à busca por recursos, apenas um está direcionado ao setor siderúrgico, compreendendo US \$ 3,5 bilhôes e correspondendo a 19\% desses investimentos, enquanto os outros quatro projetos, além de representarem maior volume de capital, ou seja, US\$15,1 bilhões, e corresponderem a 80\%, concentram-se no setor de energia, especialmente no segmento de petróleo e gás (Gráfico 11).

Gráfico 11. Distribuição dos investimentos chineses no território fluminense por setores entre 2010-2013

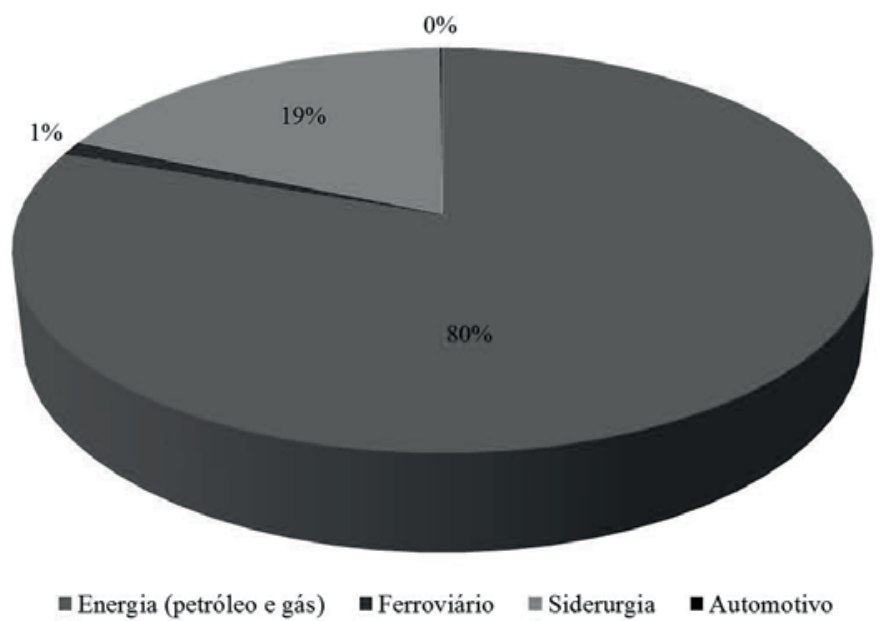

Fonte: Oliveira (2012) e CEBC (2013, 2014 e 2015). Gráfico elaborado pelo autor.

O modo de entrada ${ }^{11}$ dos investimentos em um país compreende Fusões e aquisições, Joint ventures e Greenfield (CEBC, 2011 b). No que concerne ao modo de entrada dos investimentos chineses no território fluminense, identifica-se que o modo Greenfield é contemplado por apenas um projeto, que se faz presente no setor automotivo. Embora apresente valor superior ao modo de entrada Greenfield, o ingresso dos investimentos pela modalidade Joint-venture também corresponde à forma utilizada pelo influxo do capital sínico no estado, com um projeto apenas, no setor siderúrgico. Por outro lado, as Fusóes e Aquisiçôes correspondem ao modo de entrada predominante, totalizando cinco projetos: um no setor siderúrgico e quatro no setor de energia. Ressalte-se que um aspecto importante acerca dessa modalidade de inserção de investimentos diz respeito à estrutura da propriedade (Gráfico 12).

\footnotetext{
11 "Tradicionalmente, distinguem-se três diferentes modos de entrada de investimentos em um país: a) Fusões e Aquisiçôes - compra total ou parcial de empresas situadas no país por um investidor estrangeiro, b) Joint Ventures - parcerias estratégicas entre empresas, que envolvem a participação acionária das empresas na criação de uma nova empresa com uma finalidade específica e c) Greenfield - construção de instalações totalmente novas no país de destino por um investidor estrangeiro, que tem o controle total da construção e operação dos ativos" (CEBC, 2011 b, p. 23).
} 
Gráfico 12. Modo de entrada dos investimentos chineses no território fluminense entre 2010-2013

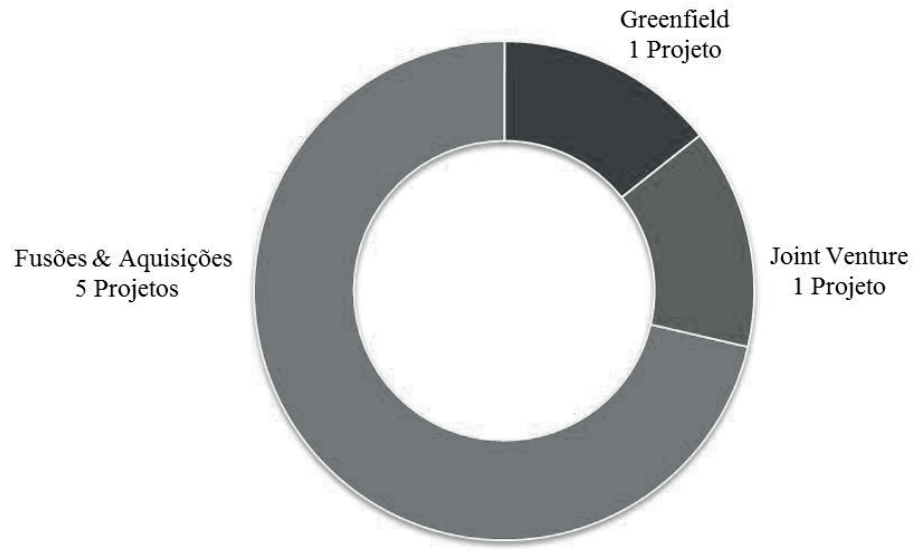

As fusões e aquisições identificadas foram efetuadas, predominantemente, por empresas estatais chinesas, tanto em volume de capital investido quanto em número de projetos. Esse quadro subsidia nossas colocaçôes acerca da inserção fluminense na base de fornecimento de recursos para a República Popular da China, sobretudo quando consideramos que o modo de entrada (Fusōes e aquisiççess), o setor (energia), o fator determinante predominante (busca por recursos) e o maior número de projetos constituem um montante do influxo do capital sínico no território e são coordenados pelas empresas estatais centrais chinesas (Central SOE), que se conformam como novas territorialidades atuantes no processo de reestruturação territorial fluminense. A localização dessas empresas chinesas no território fluminense, ou seja, desses novos atores, é apresentada na Tabela 6 e na Figura 3.

Tabela 6. Empresas chinesas que investiram no território fluminense entre 2010-2013

\begin{tabular}{|l|l|l|l|}
\hline Empresa chinesa & Setor & Município fluminense & Região de governo \\
\hline Sinopec & Energia & Rio de Janeiro & Metropolitana \\
\hline Sinochem & Energia & Rio de Janeiro & Metropolitana \\
\hline CNOOC & Energia & Rio de Janeiro & Metropolitana \\
\hline $\begin{array}{l}\text { Wuhan Iron/Steel Group } \\
\text { (Wisco) }\end{array}$ & Siderúrgico & São João da Barra & Norte Fluminense \\
\hline China Northern Railway & Ferroviário & Três Rios & Centro-Sul Fluminense \\
\hline CR Zongshen & Automotivo & Sapucaia & Centro-Sul Fluminense \\
\hline
\end{tabular}

Fonte: Elaborada pelo autor.

A Tabela 6 evidencia a presença dessas empresas em diferentes municípios e regiōes de governo do estado do Rio de Janeiro, ressaltando-se os seguintes aspectos: i) as empresas que não estão relacio- 
nadas ao setor de energia têm suas plantas localizadas no interior fluminense, ao passo que ii) as estatais chinesas vinculadas a esse setor têm seus escritórios de representação e atividades administrativas na metrópole fluminense, como, por exemplo, a CNOOC, a Sinochem e a Sinopec, com grande parte do capital investido envolvida em atividades de exploração petrolífera offshore. A Figura 3 evidencia a espacialização desses investimentos no território fluminense, identificando Rio de Janeiro, São João da Barra, Três Rios e Sapucaia como municípios receptores dos investimentos chineses destinados ao estado do Rio de Janeiro entre 2010-2013.

Figura 3. Estado do Rio de Janeiro: municípios receptores de investimentos chineses

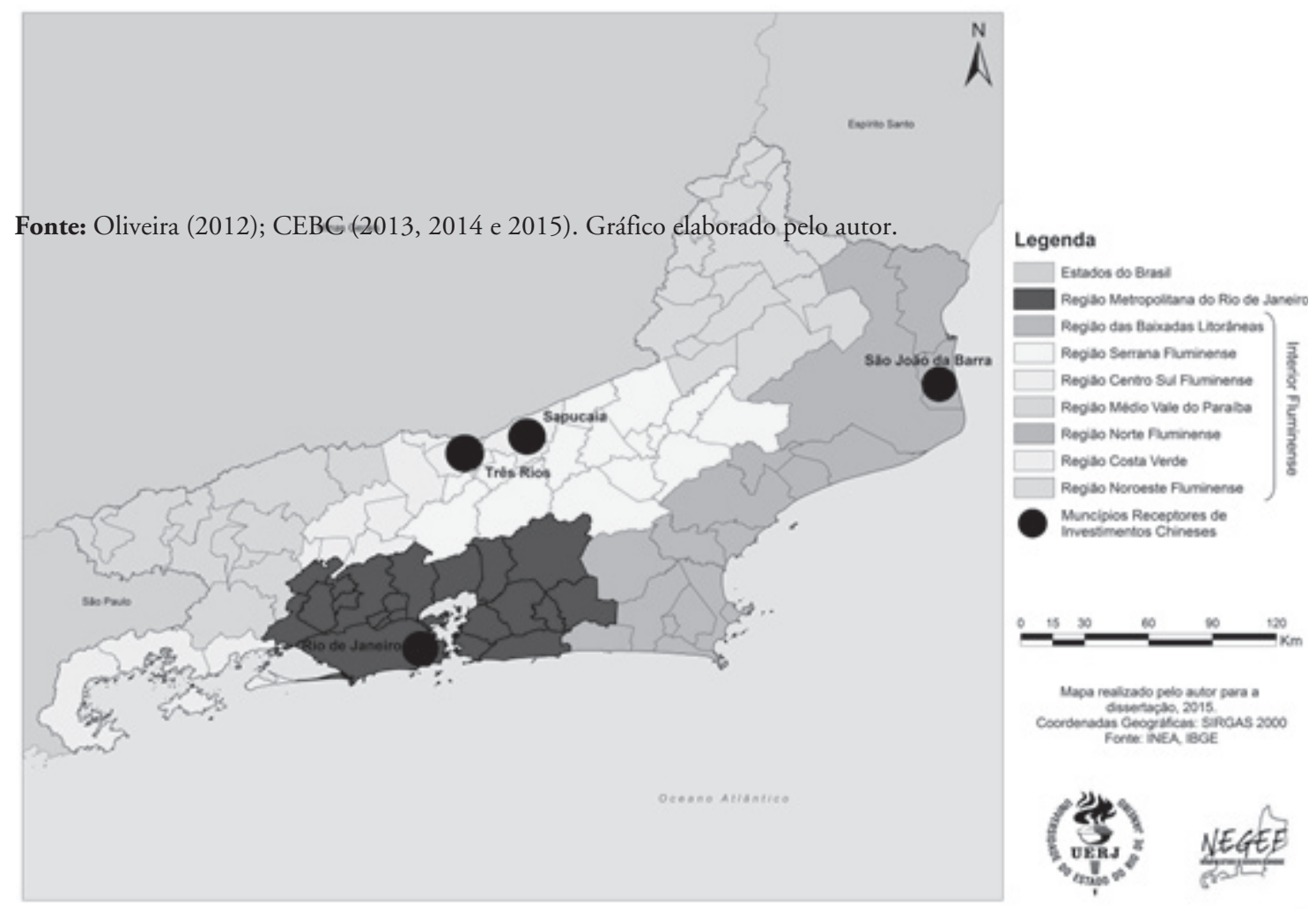

Fonte: Elaborado pelo autor. 


\section{Considerações finais}

Durante o século XX, a trajetória econômica fluminense caracterizou-se pela dupla perda de centralidade, porém, da década de 1990 em diante, o estado do Rio de Janeiro apresentou-se como um território em mutação, caracterizado pela reorientação do fluxo de investimentos em direção ao interior, o que acarretou a dispersão das atividades produtivas no território, com a instalação de novas plantas industriais em suas porções setentrional e meridional. Em consequência, irrompeu o século XXI como a segunda maior economia nacional, tendo seu processo de reestruturação territorial fundamentado na interiorização econômica decorrente da implantação de novas atividades produtivas no território e da reorientação dos fluxos de investimentos.

Observa-se ainda que o processo de reestruturação territorial fluminense, com a recente retomada do crescimento econômico, contou com a participação do influxo de capitais sínicos. A abertura econômica realizada pela República Popular da China nas últimas décadas do século XX, assentada no comércio exterior e nos investimentos internacionais, mostrou-se decisiva. Houve, portanto, aumento de sua participação nos fluxos e estoques de IED no mundo.

Nesse contexto, o aumento do influxo de capital sínico no território nacional marcou uma nova fase nas relações entre China e Brasil, sendo o ano 2010 um ponto de inflexão na trajetória desses investimentos. Nesse mesmo ano, houve considerável aumento na recepção de IED em nosso país, alcançando aproximadamente US\$ 13 bilhões.

Na Região Sudeste, o estado do Rio de Janeiro, entre 2010 e 2013, recebeu US\$ 18,8 bilhões, abrangendo sete projetos, que contemplaram os setores automotivo, ferroviário, siderúrgico e de energia.

O setor automotivo contou com a menor parcela dos investimentos chineses, tendo o Greenfield como seu modo de entrada. Os investimentos realizados nesse setor corresponderam à implantação de uma fábrica, cujo objetivo (tal qual em relação ao setor ferroviário) contemplou a busca por mercado.

O investimento no setor ferroviário ocorreu por Fusão e aquisição por uma empresa estatal chinesa.

O setor siderúrgico, por sua vez, foi contemplado pelo segundo maior volume de investimento no território fluminense, cujo modo de entrada Joint-venture marcou a inserção de uma grande empresa chinesa do ramo. Esse setor foi superado apenas pelos investimentos chineses direcionados ao setor de energia, e o fator determinante foi a busca por recurso.

No setor de energia, os projetos se destacaram tanto em volume quanto em número de projetos coordenados por grandes estatais chinesas, as quais, por meio de Fusão e aquisição, passaram a atuar como novas territorialidades no processo de reestruturação fluminense, sobretudo por terem, como determinante desses investimentos, a busca por recursos.

Registra-se que as empresas estatais chinesas, ao materializarem os IED chineses no território fluminense, visam assegurar o fornecimento e a diversificação dos fornecedores de petróleo à maior economia asiática. 


\section{Referências}

ALVES, André Gustavo de Miranda Pineli. "As relações de investimento direto entre a China e os países de seu entorno”. In (org.). Os BRICS e seus vizinhos: investimento direto estrangeiro. Brasília: Ipea, 2014.

ARAÚJO, Victor Leonardo e MELO, Hildete Pereira de. "O processo de esvaziamento industrial em São Gonçalo no século XX: auge e declínio da 'Manchester Fluminense”. Cadernos do Desenvolvimento Fluminense, Rio de Janeiro, n. 4, mai. 2014. Disponível em: www.e-publicacoes.uerj.br/ index.php/cdf/article/download/11532/9081. Acesso em: 09 jun. 2016.

ARRIGHI, Giovanni. Adam Smith em Pequim: origens e fundamentos do século XXI. São Paulo: Boitempo, 2008.

- O longo século XX: dinheiro, poder e origem de nosso tempo. Rio de Janeiro: Contraponto, 2012.

BAPTISTA, Thiago Jeremias. Os investimentos da República Popular da China no estado do Rio de Janeiro: novas territorialidades no processo de reestruturação territorial fluminense no início do século XXI (2010-2013) (dissertação). UERJ, 2016.

BONIFACE, Pascal e VÉDRINE, Hubert. Atlas do mundo global. São Paulo: Estação Liberdade, 2009.

BUCKLEY, Peter et al. "The determinants of Chinese outward foreign direct investment". Journal of International Business Studies, v. 37, n. 4, 2007, pp. 499-518.

—. "Historic and emergent trends in Chinese outward direct investment". In BUCKLEY, P. J. Foreign Direct Investment, China and the World Economy. Palgrave Macmillan, 2010.

CEBC. Carta Brasil China. Rio de Janeiro, $1^{\circ}$ mar. 2011 a.

- Investimentos chineses no Brasil: uma nova fase da relação Brasil-China. Rio de Janeiro, 2011 b.

- China up date Brazil. Rio de Janeiro, 5 ago. 2012.

—. Uma análise dos investimentos chineses no Brasil: 2007-2012. Rio de Janeiro, 2013.

—. Boletim de Investimentos Chineses no Brasil (2012-2013). Rio de Janeiro, 2014.

- Oportunidades de comércio e investimento na China para setores selecionados. Rio de Janeiro: CEBC, 2015.

CEPERJ. Estado do Rio de Janeiro: regioes de governo e municípios: 2014. Disponível em: http://www. fesp.rj.gov.br/ceep/info_territorios/Reg\%20Gov_2013.pdf. Acesso em: 20 mar. 2015.

—. PIB estadual 1995-2012. Disponível em: http://www.ceperj.rj.gov.br/ceep/pib/pib.html. Acesso em: 8 nov. 2015.

—. PIB estadual 2010-2014. Disponível em: http://www.ceperj.rj.gov.br/ceep/pib/pib.html. Acesso em: 8 nov. 2015.

—. PIB municipal 1999-2012. Disponível em: http://www.ceperj.rj.gov.br/ceep/pib/pib.html. Acesso em: 8 nov. 2015.

CHINABILITY. FDI inflows into China 1984-2014. Disponível em: http://www.chinability.com/ FDI.htm. Acesso em: 8 nov. 2015.

—. ODI from China 1990-2014. Disponível em: http://www.chinability.com/ODI.htm. Acesso em: 8 nov. 2015 . 
GONÇALVES, Williams da Silva. "A presença da China na África”. In JOBIM, Nelson et al. (orgs.). Segurança internacional: perspectivas brasileiras. Rio de Janeiro: FGV, 2010, v. 1, pp. 523-38.

IPEA. "Internacionalização das empresas chinesas: as prioridades do investimento direto chinês no mundo". Comunicados do IPEA, n. 84, 2011.

JABBOUR, Elias Marco Khalil. Projeto nacional, desenvolvimento e socialismo de mercado na China de hoje (tese). USP, 2010.

KISSINGER, Henry. Sobre a China. Rio de Janeiro: Objetiva, 2011.

LYRIO, Maurício Carvalho. A ascensão da China como potência: fundamentos politicos internos. Brasília: Funag, 2010.

MARAFON, Glaucio José et al. Regióes de governo do estado do Rio de Janeiro: uma contribuição geográgica. Rio de Janeiro: Gramma, 2005.

—. Geografia do estado do Rio de Janeiro: da compreensão do passado aos desafios do presente. Rio de Janeiro: Gramma, 2011.

MELO, Hildete Pereira de. "A trajetória da industrialização do Rio de Janeiro". In FREIRE, Américo et al. (orgs.). Um estado em questão: os 25 anos do Rio de Janeiro. Rio de Janeiro: FGV, 2001, pp. 219-48.

OLIVEIRA, A. L. S. O investimento direto das empresas chinesas no Brasil: um estudo exploratório (dissertação). UFRJ, 2012.

OLIVEIRA, Floriano José Godinho de. Reestruturação produtiva e regionalização econômica do território fluminense. São Paulo: Garamond, 2008.

—. "Políticas territoriais e integração do 'novo' território do estado do Rio de Janeiro". In EGLER, Tamara Tania Cohen e TAVARES, Hermes Magalhães (orgs.). Política pública, rede social e território. Rio de Janeiro: Letra Capital, 2012.

RIBEIRO, Valéria Lopes. A China e a economia mundial: uma abordagem sobre a ascensão chinesa na segunda metade do século XX (dissertação). Universidade Federal de Santa Catarina, 2008.

—. "A expansão chinesa na África: o desafio do crescimento e a nova face do imperialismo econômico". Oikos, Rio de Janeiro, v. 9, n. 2, 2010.

—. A expansão chinesa e seus impactos na África na primeira década do século XXI (tese). Universidade Federal do Rio de Janeiro, 2013.

SANTOS, Milton. "O retorno do território". In — et al. Território: globalização e fragmentação. São Paulo: Hucitec, 1996, pp. 15-21.

— e SILVEIRA, M. L. O Brasil: território e sociedade no início do século XXI. 10 ed. Rio de Janeiro: Record, 2008.

SILVA, Robson Dias. Indústria e desenvolvimento regional no Rio de Janeiro. Rio de Janeiro: FGV, 2012. SOUZA, Marcelo Lopes. Os conceitos fundamentais da pesquisa socioespacial. Rio de Janeiro: Bertrand Brasil, 2013.

TERRA, Denise Cunha Tavares et al. "A reestruturação econômica e territorial do Norte fluminense". In MONIÉ, F. e BINSZTOK, J. (orgs.). Geografia e geopolitica do petróleo. Rio de Janeiro: Mauad, 2012.

UNCTAD. China. Disponível em: http://unctad.org/Sections/dite_fdistat/docs/webdiaeia2014d3_ CHN.pdf. Acesso em: 8 nov. 2015. 